\title{
THE SULPHIDATION OF CALCINED LIMESTONE WITH HYDROGEN SULPHIDE AND CARBONYL SULPHIDE
}

\author{
A. B. M. HEESINK ${ }^{\dagger}$ and W. P. M. VAN SWAAIJ \\ Department of Chemical Engineering, Twente University of Technology, PO Box 217, 7500 AE Enschede,
} The Netherlands

(First received 18 November 1994; revised manuscript received 3 March 1995; accepted 9 March 1995)

\begin{abstract}
The sulphidation of calcined limestone with $\mathrm{H}_{2} \mathrm{~S}, \mathrm{COS}$ and mixtures of $\mathrm{H}_{2} \mathrm{~S}$ and COS was studied in a thermogravimetric analyzer at temperatures between 500 and $700^{\circ} \mathrm{C}$. The applied $\mathrm{H}_{2} \mathrm{~S}$ - and COS-pressures corresponded with those in coal gas produced by modern coal gasifiers, i.e. 50-12,000 $\mathrm{Pa}$ for $\mathrm{H}_{2} \mathrm{~S}$ and $50-1000 \mathrm{~Pa}$ for $\mathrm{COS}$. The reaction orders in $\mathrm{H}_{2} \mathrm{~S}$ and $\mathrm{COS}$ as well as the activation energies of the involved reactions were determined. The mechanism of sulphidation was examined by simulating measured conversion vs time behaviour with the grain size distribution model of Heesink et al. (1993, Chem. Engng J. $53,25-37)$
\end{abstract}

\section{INTRODUCTION}

Thermodynamic calculations have shown that the oxides of the metals $\mathrm{Ca}, \mathrm{Sr}, \mathrm{Ba}, \mathrm{V}, \mathrm{Mo}, \mathrm{W}, \mathrm{Mn}, \mathrm{Fe}, \mathrm{Co}$, $\mathrm{Cu}$ and $\mathrm{Zn}$ can be used as sulphur sorbents to be applied for high-temperature coal gas desulphurization (Westmoreland and Harrison, 1976). On basis of these metals, many sorbents have been developed [see e.g. Venkataraman et al. (1991) and Clift and Seville (1993)]. One can roughly discriminate between synthetic sorbents, which are relatively expensive but have a long lifetime, and natural sorbents which are cheap but possibly are less stable. Sorbents that belong to the category of natural sorbents are iron ore and limestone, either in raw or calcined form. Borgwardt and Roache (1984), and more recently Illerup et al. (1993), examined the reaction between limestone and $\mathrm{H}_{2} \mathrm{~S}$. Borgwardt and Roache concluded that limestone conversion extents of more than $25 \%$ can only be obtained with very small limestone particles $(<10 \mu \mathrm{m})$. In agreement with that, Illerup et al. found that bigger limestone particles (360-1500 $\mu \mathrm{m})$ only show satisfactory sulphidation rates at $\mathrm{CO}_{2}$-pressures low enough to allow calcination of the limestone. Therefore, in this work we concentrated on calcined limestone. The application of calcined limestone (which mainly consists of $\mathrm{CaO}$ ) in coal gas clean-up processes may offer the following advantages.

- Thermodynamic calculations [based on data from Barin (1989)] show that the concentrations of both $\mathrm{H}_{2} \mathrm{~S}$ and $\mathrm{COS}$ can be reduced to sufficiently low values according to the reactions

$$
\begin{aligned}
& \mathrm{CaO}+\mathrm{H}_{2} \mathrm{~S} \rightarrow \mathrm{CaS}+\mathrm{H}_{2} \mathrm{O} \\
& \mathrm{CaO}+\mathrm{COS} \rightarrow \mathrm{CaS}+\mathrm{CO}_{2} .
\end{aligned}
$$

\footnotetext{
${ }^{\dagger}$ Corresponding author.
}

- Calcined limestone is also able to absorb halogens like $\mathrm{HCl}$ (van der Ham et al., 1995) and HF:

$$
\begin{aligned}
& \mathrm{CaO}+2 \mathrm{HCl} \rightarrow \mathrm{CaCl}_{2}+\mathrm{H}_{2} \mathrm{O} \\
& \mathrm{CaO}+2 \mathrm{HF} \rightarrow \mathrm{CaF}_{2}+\mathrm{H}_{2} \mathrm{O} .
\end{aligned}
$$

- Limestone has a low price of typically some $\mathbf{4 0}$ US $\$$ or 30 ECU per ton, including transport. Because of its low price, limestone may be applied for non-regenerative desulphurization.

- In most cases regenerative desulphurization is to be preferred. Sulphided limestone can be regenerated by partial oxidation with $\mathrm{SO}_{2}$ and subsequent reaction between remaining $\mathrm{CaS}$ and $\mathrm{CaSO}_{4}$, according to (van der Ham et al., 1995)

$$
\begin{array}{r}
\mathrm{CaS}+2 \mathrm{SO}_{2} \rightarrow \mathrm{CaSO}_{4}+\mathrm{S}_{2} \\
\mathrm{CaS}+3 \mathrm{CaSO}_{4} \rightarrow 4 \mathrm{CaO}+4 \mathrm{SO}_{2} .
\end{array}
$$

This regeneration route offers the advantage that elemental sulphur is obtained. A drawback, however, is the high temperature (about $950^{\circ} \mathrm{C}$ ) which is needed for reaction (R6) to proceed.

- Spent sulphided limestone could be (partly) used as a fluxing agent in entrained flow coal gasifiers or as a building material after oxidation towards gypsum.

A disadvantage of calcined limestone is its ability to absorb $\mathrm{CO}_{2}$. At partial $\mathrm{CO}_{2}$-pressures higher than the equilibrium pressure, the absorption of $\mathrm{CO}_{2}$ may interfere with the absorption of $\mathrm{H}_{2} \mathrm{~S}$ and $\mathrm{COS}$. A future paper will deal with that matter.

To enable the design of an absorber in which coal gas is desulphurized with calcined limestone, sulphidation kinetics must be known. These can be revealed by measuring the sulphidation rate of calcined limestone in the presence of (simulated) coal gas. In general, the conversion rate of a reacting solid can be 
formulated as

$$
\frac{\mathrm{d} X}{\mathrm{~d} t}=k_{A} \exp \left[-\frac{E_{\mathrm{act}}}{R T}\right] C^{n} f(X) .
$$

The values of the Arrhenius constant $k_{A}$, the activation energy $E_{\text {act }}$, the reaction order $n$ and the function $f(X)$ will thus determine the rate of sulphidation at given values of temperature $T$ and concentration $C$. It is to be expected that the value of $k_{A}$ will depend on the chemical and physical properties of the calcined limestone (e.g. specific surface area) which in their turn are related to the origin of the limestone and/or the calcination history. It is likely that the values of $E_{\text {act }}, n$ and $f(X)$ are less dependent on limestone type. The function $f(X)$ expresses the dependency of the sulphidation rate on the extent of conversion, $X$. This dependency is determined by the sulphidation mechanism.

The sulphidation kinetics of calcined limestone and fully calcined dolomite (i.e. $\mathrm{CaO} \cdot \mathrm{MgO}$ with $\mathrm{CaO}$ being reactive only) have been studied in the past (Squires et al., 1969; Pell, 1971; Westmoreland et al., 1977; Yang and Chen, 1979; Attar and Dupuis, 1979; Kamath and Petrie, 1981; Proy, 1982; Borgwardt et al., 1984; Yumura and Furimsky, 1985) and more recently by Abbasian et al. $(1991,1993)$, Sotirchos (1991), and Nguyen and Watkinson (1993). Nevertheless, there is no consensus yet about the magnitude of typical kinetic data like reaction orders and activation energies. Westmoreland et al. (1977), for example, examined the reaction between calcined limestone and $\mathrm{H}_{2} \mathrm{~S}$ and reported first-order behaviour in $\mathrm{H}_{2} \mathrm{~S}$ and an activation energy of $22 \mathrm{~kJ} \mathrm{~mol}^{-1}$. Yang and Chen (1979) examined the reaction between calcined limestone and $\operatorname{COS}$ and found first-order behaviour in COS and an activation energy of $18 \mathrm{~kJ} \mathrm{~mol}^{-1}$. Others measured much higher activation energies of about $130 \mathrm{~kJ} \mathrm{~mol}^{-1}$ for both reactions (Squires et al., 1969; Borgwardt et al., 1984). The sulphidation mechanism has been examined by Borgwardt et al. (1984) and by Nguyen and Watkinson (1993). Borgwardt et al. (1984) concluded that diffusion of the $\mathrm{H}_{2} \mathrm{~S}$ through the sulphided layer towards the unreacted $\mathrm{CaO}$-surface is rate determining. However, Nguyen and Watkinson (1993) reported that the reaction at the surface is rate determining during the initial stage of sulphidation and that diffusion through the product layer becomes rate determining thereafter.

To get a better insight we examined the sulphidation of calcined limestone in an atmospheric thermogravimetric analyzer. Sulphidation was performed with either $\mathrm{H}_{2} \mathrm{~S}, \mathrm{COS}$ or mixtures of $\mathrm{H}_{2} \mathrm{~S}$ and $\mathrm{COS}$ at temperatures between 500 and $700^{\circ} \mathrm{C}$. The applied $\mathrm{H}_{2} \mathrm{~S}$ - and COS-pressures corresponded with those in coal gas, i.e. $50-12,000 \mathrm{~Pa}$ for $\mathrm{H}_{2} \mathrm{~S}$ and $50-1000 \mathrm{~Pa}$ for COS. For reactions (R1) and (R2) the respective orders in $\mathrm{H}_{2} \mathrm{~S}$ and $\mathrm{COS}$ as well as the activation energies were established. It was also examined how sulphidation is affected by the presence of $\mathrm{H}_{2}$ and $\mathrm{CO}$, which are the main constituents of coal gas. Finally, the sulphidation mechanism was examined by means of the grain size distribution model of Heesink et al. (1993).

\section{EXPERIMENTAL DETAILS}

A simplified flow scheme of the applied experimental set-up is shown in Fig. 1. The applied ThermoGravimetric Analyser (TGA) was of the Setaram TG85 type. The samples were kept in a small cup $(\varnothing=9.5 \mathrm{~mm}$ ) made out of quartz, which hung on a platinum wire inside a quartz tube $(\varnothing=15 \mathrm{~mm}$ ). The tube was placed in an oven which can be operated at temperatures between 20 and $1000^{\circ} \mathrm{C}$. The sample temperature was indirectly measured by a thermocouple placed at sample height in between the quartz tube and the inner wall of the oven. Previous tests had shown that the difference between the temperature at this location and the temperature of the sample (measured inside the quartz tube just below the sample cup) was not more than $2^{\circ} \mathrm{C}$. The TGA was connected to a computer for data acquisition and control purposes. The gas mixture, which could contain $\mathrm{H}_{2} \mathrm{~S}, \mathrm{COS}, \mathrm{H}_{2}, \mathrm{CO}$ and $\mathrm{He}$, was composed with the help of electronic mass flow controllers that received their set-points from the computer. All gases were taken from bottles. The stream through the TGA, which was directed downwards to optimize mass transfer between the gas bulk and the particles inside the sample cup, was adjusted to $400 \mathrm{ml} \mathrm{min}^{-1}$ (STP). The upper section of the TGA, containing the delicate electronic parts of the balance, was continuously purged with $\mathrm{He}$ (at a flow rate of $40 \mathrm{ml} \mathrm{min}^{-1}$ STP) to prevent the corrosive sulphidation gas from entering.

It was found that quite some sulphur adsorbed at the inner surface of the stainless steel supply line. In some cases it took about $1 \mathrm{~h}$ before the gas entering the TGA had the composition that was selected by means of the mass flow controllers. Therefore, before starting an experiment, the supply line was purged for at least $90 \mathrm{~min}$ with the selected gas mixture. During purging the gas mixture was bypassed to the scrubber. In the meantime, the TGA (already containing the sample) was purged with $\mathrm{He}$ that was supplied through a separate line. After purging, the sulphidation gas was switched to the TGA, whereas the He purge stream was simultaneously switched to the scrubber by means of two three-way valves. Before entering the TGA and coming into contact with the sample, each gas stream was sent through separate packed-bed reactors containing copper-based catalyst pellets (type BASF R3-11). This was done to remove any $\mathrm{O}_{2}$ possibly present in the gas streams in order to avoid the unwanted oxidation of the sulphided limestone sample. In the catalyst beds $\mathrm{O}_{2}$ is either converted towards $\mathrm{H}_{2} \mathrm{O}$ (if $\mathrm{H}_{2}$ is present) or absorbed under the formation of $\mathrm{CuO}$. To avoid the absorption of sulphur by the catalyst, $\mathrm{H}_{2} \mathrm{~S}$ and $\mathrm{COS}$ were added to the sulphidation gas behind the catalyst bed. $\mathrm{H}_{2}$ was used for periodic regeneration of the catalyst.

Sulphidation experiments were performed with limestone from the quarry at Wülfrath (Germany). All 


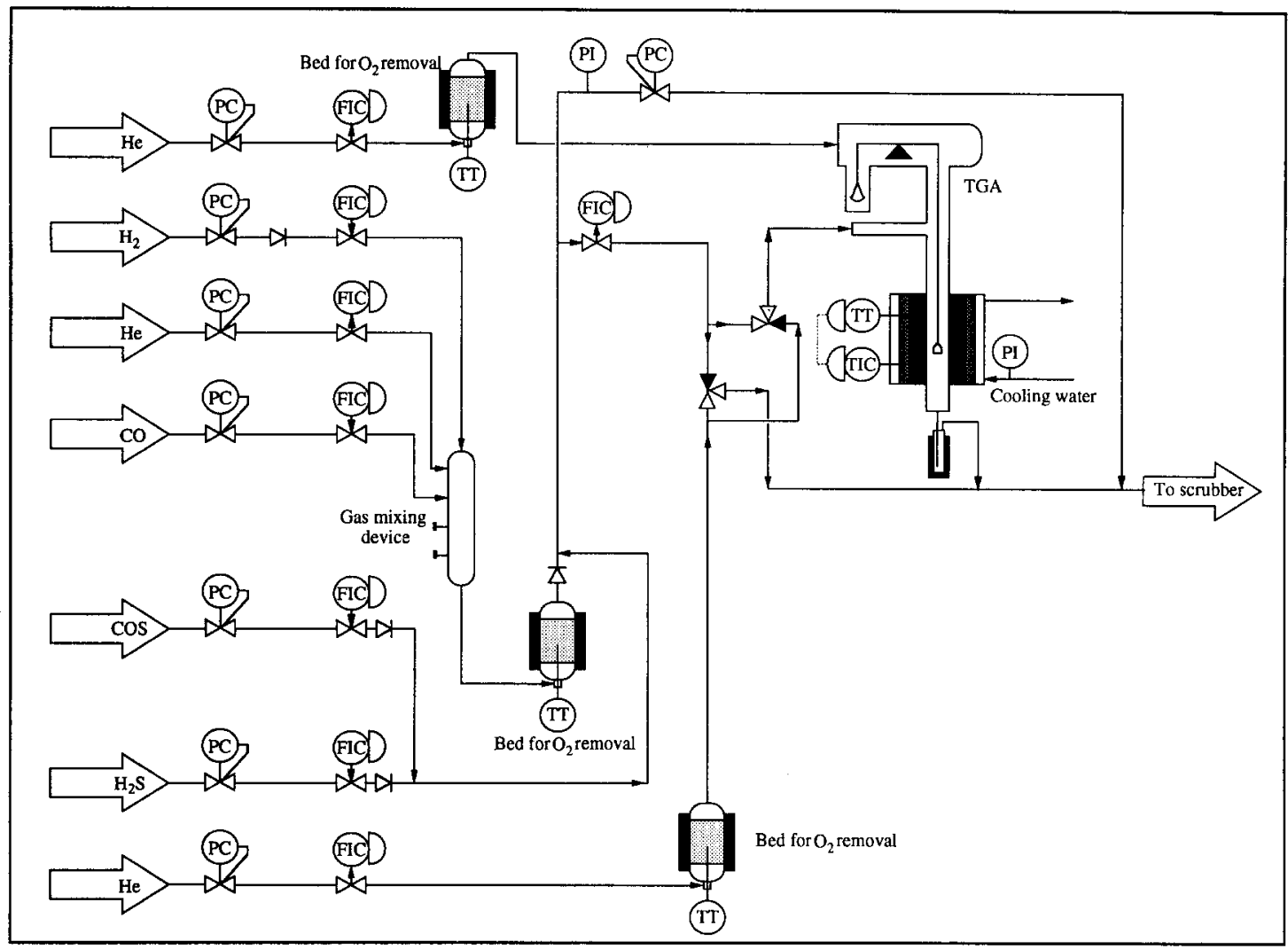

Fig. 1. A simplified flowsheet of the applied experimental set-up.

samples were taken from a single batch of $1 \mathrm{~g}$ limestone which was previously calcined in the TGA at $850^{\circ} \mathrm{C}$ for $30 \mathrm{~min}$ while purging with $\mathrm{He}$. This batch was stored in an airtight chamber which was purged with $\mathbf{N}_{2}$. Table 1 gives the composition of the applied limestone before and after calcination. Figure 2 shows a mercury porosigram of the calcined material indicating a specific surface area of $16.8 \mathrm{~m}^{2} \mathrm{~g}^{-1}$. The diameter of the applied particles ranged from 150 to $210 \mu \mathrm{m}$.

Table 1. Chemical composition of the applied Wülfrath limestone before and after calcination (in wt \%)

\begin{tabular}{ccc}
\hline Component & $\begin{array}{c}\text { Before } \\
\text { calcination }\end{array}$ & $\begin{array}{c}\text { After } \\
\text { calcination }\end{array}$ \\
\hline $\mathrm{CaCO}_{3}$ & 97.20 & - \\
$\mathrm{MgCO}_{3}$ & 0.90 & - \\
$\mathrm{CaO}$ & - & 95.90 \\
$\mathrm{MgO}$ & - & 0.76 \\
$\mathrm{Si}$ & 0.54 & 0.95 \\
$\mathrm{Fe}$ & 0.09 & 0.16 \\
$\mathrm{Al}$ & 0.06 & 0.11 \\
$\mathrm{~S}$ & 0.02 & 0.04 \\
$\mathrm{~K}$ & 0.02 & 0.04 \\
$\mathrm{Sr}$ & 0.02 & 0.04 \\
\hline
\end{tabular}

${ }^{\dagger}$ Calculated from the composition before calcination assuming complete calcination.
Experiments were carried out with relatively small samples of $3 \mathrm{mg}$ to ensure differential operation and to minimize the influence of mass and heat transport resistances located around the sample cup and between the particles inside the cup. Before starting a sulphidation experiment, the samples were heated at $850^{\circ} \mathrm{C}$ for $10 \mathrm{~min}$ while purging with $\mathrm{He}$ to remove impurities possibly absorbed by the calcined material during storage. Then the temperature was adjusted. When the desired sulphidation temperature was reached, the He purge gas was replaced by sulphidation gas. Unless stated otherwise, 4 vol. $\%$ of $\mathrm{H}_{2}$ was supplied to the sulphidation gas when sulphidation was carried out with $\mathrm{H}_{2} \mathrm{~S}$. This was done to suppress the dissociation of $\mathrm{H}_{2} \mathrm{~S}$ to elemental sulphur. For similar reasons 8 vol. $\% \mathrm{CO}$ was supplied when sulphidation was carried out with COS. When sulphidation was carried out with a mixture containing both $\mathrm{H}_{2} \mathrm{~S}$ and $\mathrm{COS} \mathrm{H}_{2}(4 \mathrm{vol} \%$ ) as well as $\mathrm{CO}(8 \mathrm{vol} . \%)$ were supplied. To optimize mass transfer all experiments were performed using helium as carrier gas.

Conversion vs time curves were derived from the corresponding weight vs time curves obtained during sulphidation. Before doing so, the weight vs time curves were smoothed by means of curve fitting to get rid of any noise (typically $50 \mu \mathrm{g}$ ). When the sample weight registered at the end of a sulphidation experiment was at least $95 \%$ of the weight expected on basis 


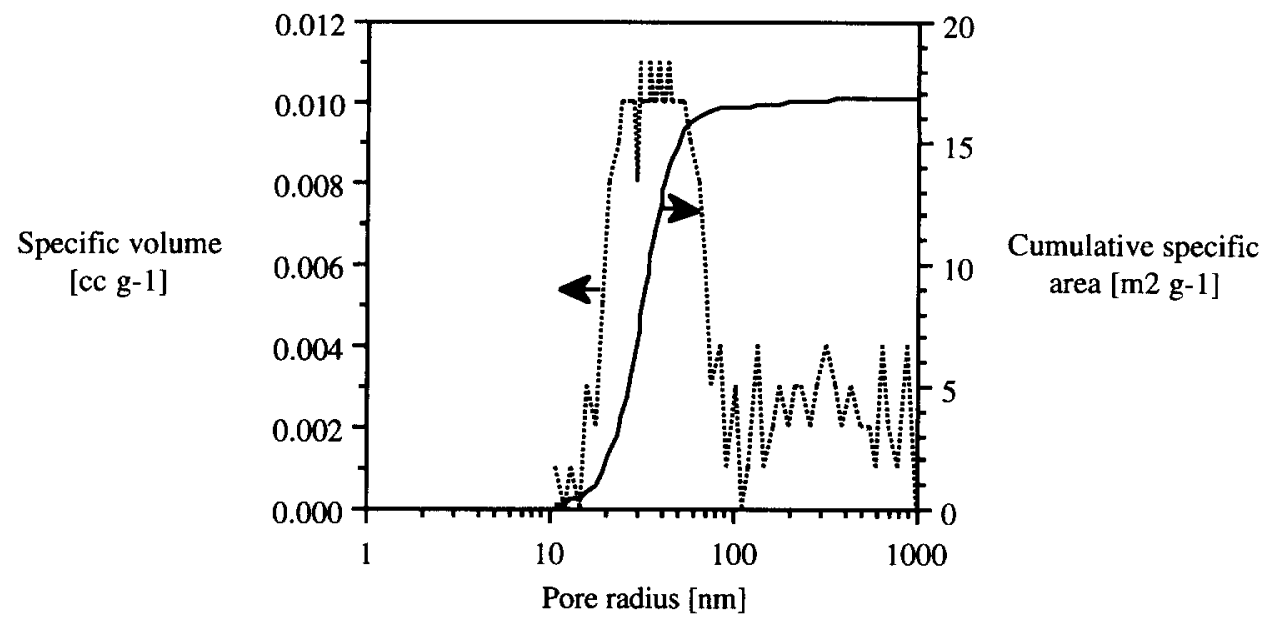

Fig. 2. Mercury porosigram of the applied calcined limestone particles (Wülfrath limestone).

of complete sulphidation (assuming an initial $\mathrm{CaO}$ content of $95.9 \mathrm{wt} \%$ ), complete conversion was assumed to be reached. In other cases conversion was calculated by assuming an initial $\mathrm{CaO}$-content of $95.9 \mathrm{wt} \%$.

\section{RESULTS}

\subsection{The influence of $\mathrm{O}_{2}$-removal}

The first sulphidation experiments were performed without employing the catalyst beds for $\mathrm{O}_{2}$-removal. In many cases ultimate conversion extents of more than $100 \%$ were calculated; values up to $130 \%$ were obtained. The formation of $\mathrm{CaSO}_{4}$, which has a much higher molecular weight than CaS (136 vs $72 \mathrm{~g}$ $\mathrm{mol}^{-1}$ ), was thought to be responsible for this. According to thermodynamics, the presence of very little $\mathrm{O}_{2}$ may lead to the formation of $\mathrm{CaSO}_{4}$ at the conditions applied. Although $\mathrm{CaSO}_{4}$ is likely to be reduced towards $\mathrm{CaS}$ by the $\mathrm{H}_{2}$ present in the sulphidation gas, a net production of $\mathrm{CaSO}_{4}$ exists when the rate of reduction is slower than the rate of oxidation. Chemical analysis showed that the sulphided samples indeed contained some $5 \mathrm{wt} \% \mathrm{CaSO}_{4}$. After installation of the catalyst beds, conversions above $100 \%$ were seldom observed, whereas the sulphate content of the sulphided samples had dropped to values of 1-2 wt $\%$. The sulphate still detected was probably produced while the samples were contacted with air in the period between experiments and chemical analysis.

A remarkable phenomenon is shown in Fig. 3 which compares the sulphidation rates obtained with $\mathrm{H}_{2} \mathrm{~S}$ before and after installation of the catalyst beds. The presence of small amounts of $\mathrm{O}_{2}$ apparently enhances sulphidation. This "enhancement" may merely be due to the higher molecular weight of $\mathrm{CaSO}_{4}$ or to some catalytic effect exercised by $\mathrm{CaSO}_{4}$. To avoid any difficulties in interpretation, all further experiments were performed with the catalyst beds in operation.

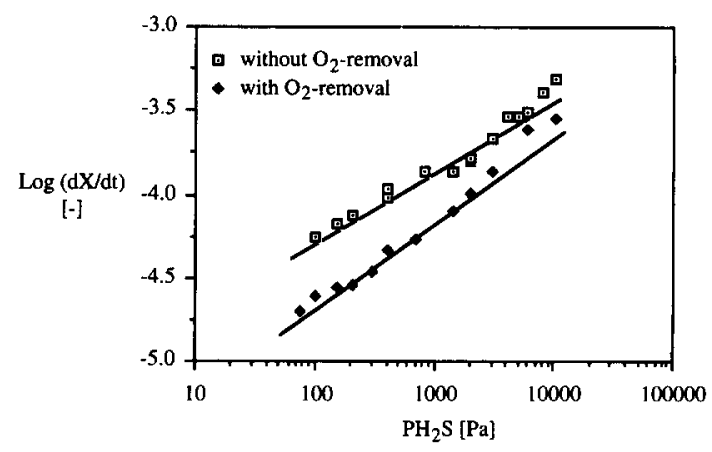

Fig. 3. Order plots for the sulphidation of calcined limestone with $\mathrm{H}_{2} \mathrm{~S}$ at $500^{\circ} \mathrm{C}$, measured before and after the installation of $\mathrm{O}_{2}$-removing catalyst beds (conversion rates calculated at a conversion extent of $30 \%$ ).

\subsection{Sulphidation with $\mathrm{H}_{2} \mathrm{~S}$}

The influence of $\mathrm{H}_{2} \mathrm{~S}$-pressure on sulphidation behaviour is illustrated in Fig. 4. The sulphidation rate clearly increases when raising the $\mathrm{H}_{2} \mathrm{~S}$-pressure. The reaction order in $\mathrm{H}_{2} \mathrm{~S}$ can be obtained by plotting the sulphidation rate at constant conversion extent (here $30 \%$ ) against $\mathrm{H}_{2} \mathrm{~S}$-pressure in a double-logarithmic way. Figure 5 shows the results obtained at temperatures of $500,600,650$ and $700^{\circ} \mathrm{C}$. At temperatures of 500 and $600^{\circ} \mathrm{C}$ the reaction order appears to be 0.5 over the whole range of applied $\mathrm{H}_{2} \mathrm{~S}$-pressures. At 650 and $700^{\circ} \mathrm{C}$ the reaction order seems to be unity at $\mathrm{H}_{2}$ S-pressures below some $1000 \mathrm{~Pa}$ and 0.5 at $\mathrm{H}_{2} \mathrm{~S}$ pressures above $1000 \mathrm{~Pa}$. However, by varying the sample weight it was found that mass transfer from the gaseous bulk to the sample cup limited the sulphidation rate when $\mathrm{H}_{2} \mathrm{~S}$-pressures below $1000 \mathrm{~Pa}$ were applied at temperatures of 650 or $700^{\circ} \mathrm{C}$. It is therefore concluded that the reaction order in $\mathrm{H}_{2} \mathrm{~S}$ is 0.5 at all applied temperatures and $\mathrm{H}_{2} \mathrm{~S}$-pressures. It was checked whether the reaction order in $\mathrm{H}_{2} \mathrm{~S}$ remains constant while sulphidation proceeds. This appeared to be roughly true: only during the first stage 


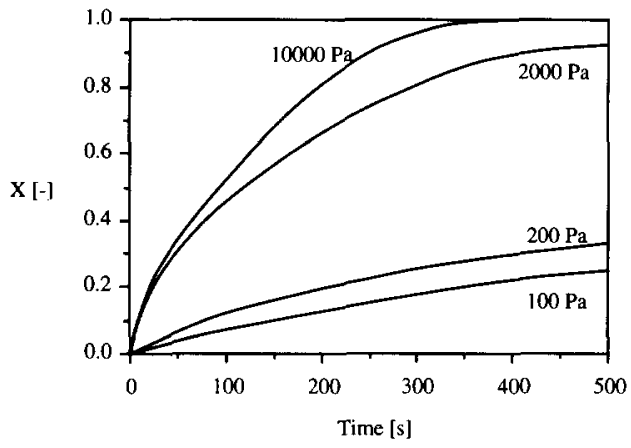

Fig. 4. Conversion vs time curves obtained for the sulphidation of calcined limestone with $\mathrm{H}_{2} \mathrm{~S}$ at $600^{\circ} \mathrm{C}$ and different $\mathrm{H}_{2} \mathrm{~S}$-pressures.

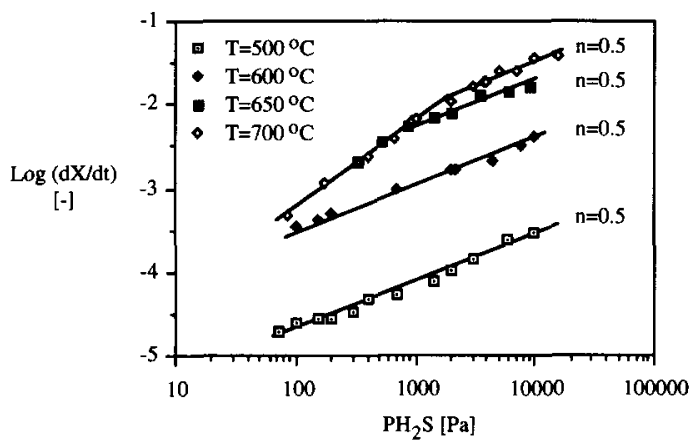

Fig. 5. Order plots for the sulphidation of calcined limestone with $\mathrm{H}_{2} \mathrm{~S}$ at $500,600,650$ and $700^{\circ} \mathrm{C}$ (conversion rates calculated at a conversion extent of $30 \%$ ).

of sulphidation $(X \approx 0)$, where the reaction rate is so high that mass transfer may limit the rate of reaction, an order of unity was sometimes found. This was especially observed when low $\mathrm{H}_{2} \mathrm{~S}$-pressures and/or high temperatures were applied.

Figure 6 shows the influence of temperature on sulphidation behaviour at a fixed $\mathrm{H}_{2} \mathrm{~S}$-pressure of $2000 \mathrm{~Pa}$. As to be expected, the sulphidation rate increases with temperature. The activation energy can be derived from the Arrhenius plot given in Fig. 7. A value of $160 \mathrm{~kJ} \mathrm{~mol}^{-1}$ is found for temperatures ranging from 500 to $700^{\circ} \mathrm{C}$. The low activation energy found at temperatures above $700^{\circ} \mathrm{C}$ is the consequence of mass transfer limitation which was clearly demonstrated by varying the sample weight, higher weights showing lower sulphidation rates.

Borgwardt et al. (1984) found that the presence of $\mathrm{H}_{2}$ may significantly suppress the rate of sulphidation. We therefore investigated the influence of $\mathrm{H}_{2}$-pressure on sulphidation behaviour. Figure 8 shows the results obtained at $500^{\circ} \mathrm{C}$. The sulphidation rate indeed decreases at increasing $\mathrm{H}_{2}$-pressures. A similar trend was observed at $600^{\circ} \mathrm{C}$.

Since the main constituent of coal gas is $\mathrm{CO}$, it was also examined whether the presence of $\mathrm{CO}$ affects sulphidation behaviour. Experiments were performed at a temperature of $600^{\circ} \mathrm{C}$. The maximum applied $\mathrm{CO}$-pressure was $8000 \mathrm{~Pa}$ to ensure that no more

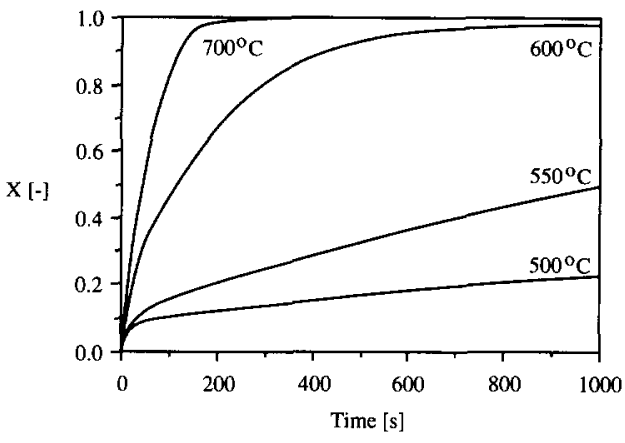

Fig. 6. Conversion vs time curves obtained for the sulphidation of calcined limestone with $\mathrm{H}_{2} \mathrm{~S}$ at a $\mathrm{H}_{2} \mathrm{~S}$-pressure of $2000 \mathrm{~Pa}$ and different temperatures.

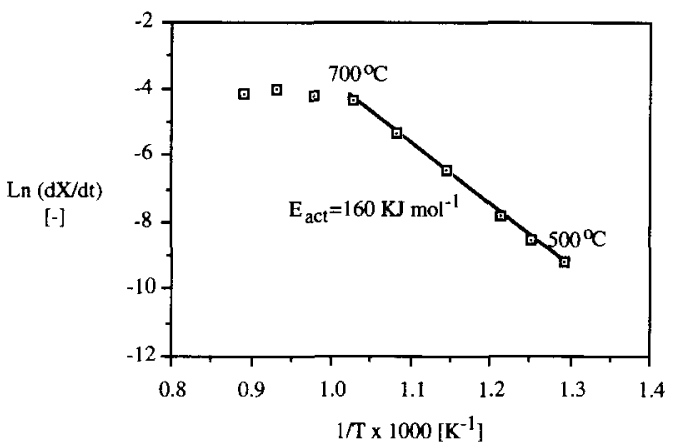

Fig. 7. Arrhenius plot for the sulphidation of calcined limestone with $\mathrm{H}_{2} \mathrm{~S}$ derived at a $\mathrm{H}_{2} \mathrm{~S}$-pressure of $2000 \mathrm{~Pa}$ (conversion rates calculated at a conversion extent of $30 \%$ ).

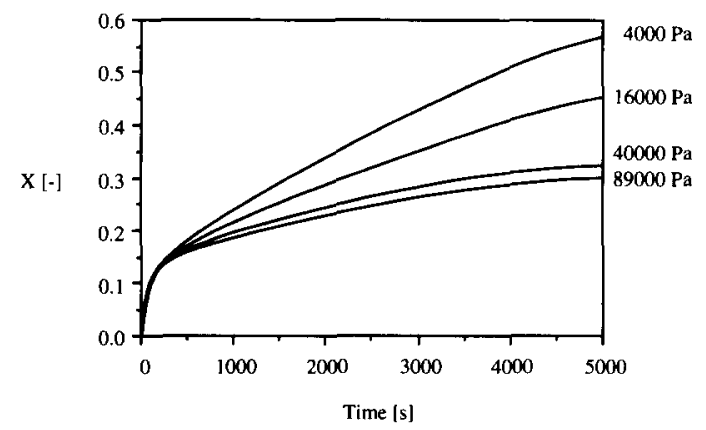

Fig. 8. Conversion vs time curves obtained for the sulphidation of calcined limestone with $\mathrm{H}_{2} \mathrm{~S}$ at temperature of $500^{\circ} \mathrm{C}$, a $\mathrm{H}_{2} \mathrm{~S}$-pressure of $2000 \mathrm{~Pa}$ and different $\mathrm{H}_{2}$-pressures.

than $5 \%$ of the $\mathrm{H}_{2} \mathrm{~S}$ was being converted towards $\mathrm{COS}$, according to the reaction

$\mathrm{H}_{2} \mathrm{~S}+\mathrm{CO} \rightarrow \mathrm{COS}+\mathrm{H}_{2}$

with $K_{\mathrm{eq}}=0.032$ at $600^{\circ} \mathrm{C}$.

Figure 9 shows that sulphidation is slightly inhibited by the presence of $\mathrm{CO}$.

\subsection{Sulphidation with $\mathrm{COS}$}

The influence of COS-pressure on the rate of sulphidation is not very pronounced (see Fig. 10). The 


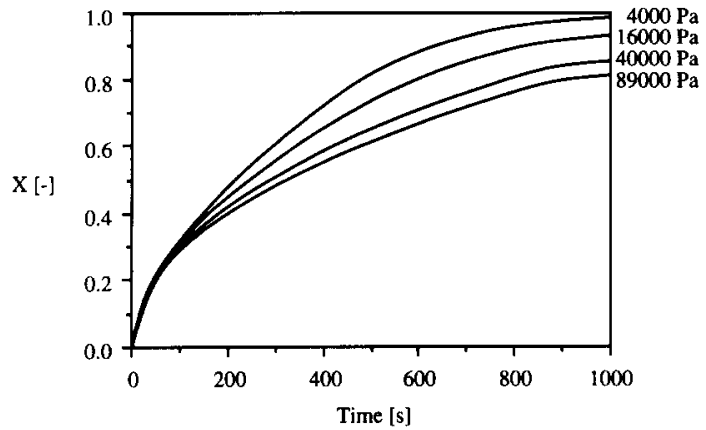

Fig. 9. Conversion vs time curves obtained for the sulphidation of calcined limestone with $\mathrm{H}_{2} \mathrm{~S}$ at a temperature of $600^{\circ} \mathrm{C}$, a $\mathrm{H}_{2} \mathrm{~S}$-pressure of $1000 \mathrm{~Pa}$ and different CO-pressures.

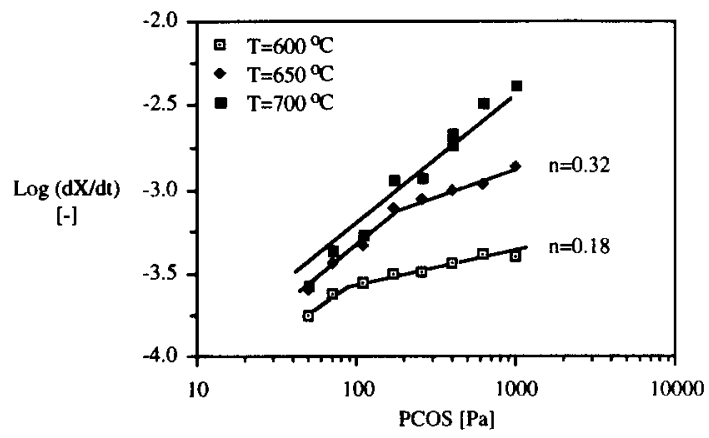

Fig. 10. Order plots for the sulphidation of calcined limestone with $\operatorname{COS}$ at 600,650 and $700^{\circ} \mathrm{C}$ (conversion rates calculated at a conversion extent of $30 \%$ ).

reaction orders in $\operatorname{COS}$ at 600 and $650^{\circ} \mathrm{C}$ amount to 0.18 and 0.32 , respectively. The reaction order at $700^{\circ} \mathrm{C}$ appears to be about unity. However, some tests performed at $700^{\circ} \mathrm{C}$ showed lower sulphidation rates at increasing sample weight, indicating that measurements were affected by mass transfer limitation.

A remarkable phenomenon was observed at relatively high COS-pressures (see Fig. 11). During a certain period the weight of the limestone samples was considerably higher than the value obtained after complete sulphidation. A possible explanation for this strange behaviour will be given later on.

The pronounced influence of temperature on sulphidation behaviour is demonstrated in Fig. 12. Since the reaction order is temperature dependent, the apparent activation energy (not corrected for this dependency) varies with COS-pressure. However, from the known reaction orders at 600 and $650^{\circ} \mathrm{C}$ the activation energy as defined by eq. (1) could be determined at $200 \mathrm{~kJ} \mathrm{~mol}^{-1}$.

\subsection{Sulphidation with mixtures of $\mathrm{H}_{2} \mathrm{~S}$ and $\mathrm{COS}$}

Kamath and Petrie (1981) performed sulphidation experiments with calcined limestone and mixtures of $\mathrm{H}_{2} \mathrm{~S}$ and $\mathrm{COS}$. They concluded that a so-called synergistic effect occurs: the sulphidation rate observed with a gas containing both $\mathrm{COS}$ and $\mathrm{H}_{2} \mathrm{~S}$ (in

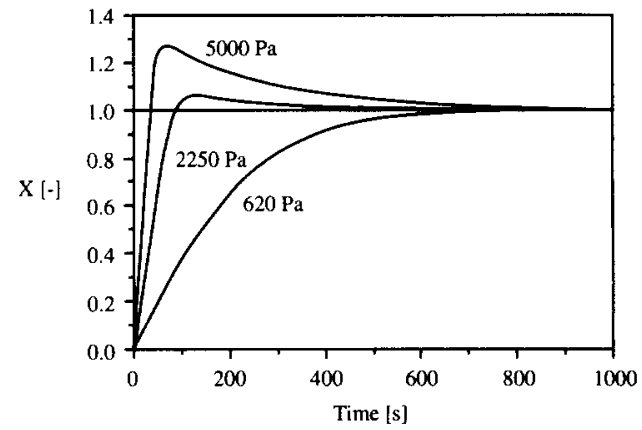

Fig. 11. Conversion vs time curves obtained for the sulphidation of calcined limestone with $\operatorname{COS}$ at $700^{\circ} \mathrm{C}$ and high COS-pressures.

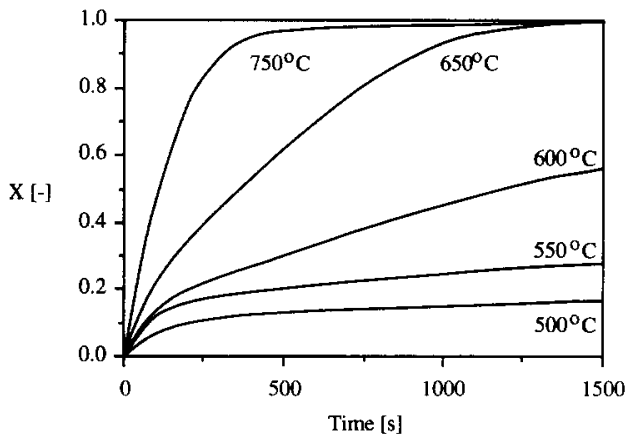

Fig. 12. Conversion vs time curves obtained for the sulphidation of calcined limestone with $\operatorname{COS}$ at a COS-pressure of $700 \mathrm{~Pa}$ and different temperatures.

a ratio of $1: 20$ ) appeared to be some $30 \%$ higher than the rate obtained with a gas containing solely $\mathrm{H}_{2} \mathrm{~S}$ (and an equal amount of sulphur). We also performed some experiments with mixtures of $\mathrm{H}_{2} \mathrm{~S}$ and $\mathrm{COS}$. All experiments were carried out at a temperature of $600^{\circ} \mathrm{C}$. To avoid misinterpretation of the experimental results, the composition of the applied gas mixtures was chosen such that conversion of $\mathrm{H}_{2} \mathrm{~S}$ into $\operatorname{COS}$ or vice versa according to reaction ( $\mathrm{R} 7)$ could not occur. Since the concentrations of $\mathrm{CO}$ and $\mathrm{H}_{2}$ were fixed at 8 and $4 \mathrm{vol} . \%$, respectively, $\mathrm{H}_{2} \mathrm{~S}$ and COS were added in a ratio of $15.6: 1$. As shown in Fig. 13, sulphidation behaviour becomes worse when COS is added to a gas mixture already containing $\mathrm{H}_{2} \mathrm{~S}$. This rather surprising result is in conflict with the observations of Kamath and Petrie (1981), but has been reproduced many times (see Fig. 14).

\section{DISCUSSION}

In this section we will interpret our results and compare them with those obtained by other investigators. We will further try to determine the mechanism of sulphidation. For this purpose the grain size distribution (GSD) model of Heesink et al. (1993) will be applied. According to this model, which is based on 


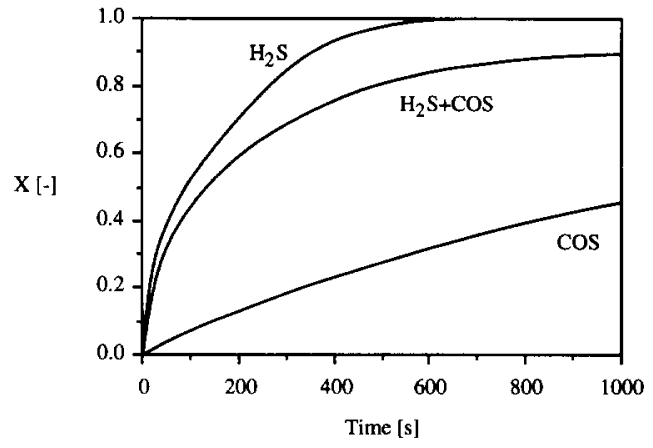

Fig. 13. Conversion vs time curves obtained for the sulphidation of calcined limestone with $\mathrm{H}_{2} \mathrm{~S}(2670 \mathrm{~Pa}), \mathrm{COS}$ $(170 \mathrm{~Pa})$ and a mixture of $\mathrm{H}_{2} \mathrm{~S}$ and $\operatorname{COS}(2670+170 \mathrm{~Pa})$ at a temperature of $600^{\circ} \mathrm{C}$.

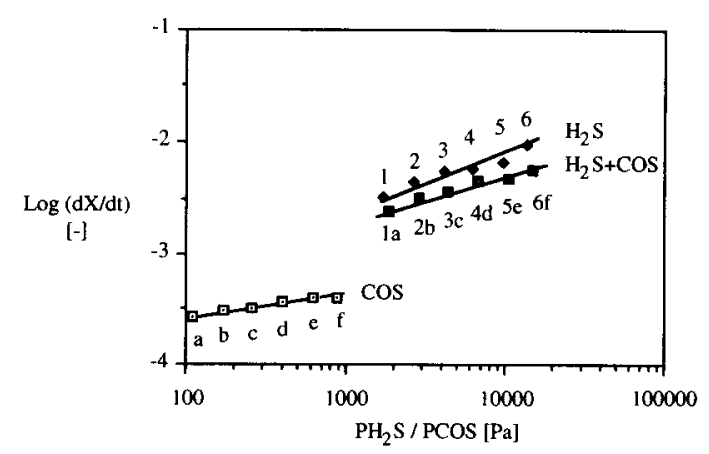

Fig. 14. Order plots for the sulphidation of calcined limestone with $\mathrm{H}_{2} \mathrm{~S}(1 \ldots 6), \mathrm{COS}$ (a...f) and mixtures of $\mathrm{H}_{2} \mathrm{~S}$ and $\operatorname{COS}(1 \mathrm{a} \ldots 6 \mathrm{f})$ at $600^{\circ} \mathrm{C}$ (conversion rates calculated at a conversion extent of $30 \%$ ).

the grain model developed by Szekely and Evans (1970), a porous solid consists of small non-porous spheres (or grains) with various sizes which are converted according to a somewhat modified version of the classical shrinking core model developed by Yagi and Kunii (1955). SEM-pictures confirm the grainy structure of calcined limestone particles (Heesink et al., 1993; Nguyen and Watkinson, 1993) and thereby the applicability of the GSD model. Before explaining the GSD model in somewhat more detail, we will first examine the possible mechanisms by which a single grain of calcined limestone may be sulphided.

\subsection{Reaction mechanism of a single grain}

Figure 15 illustrates the different steps that may play a role during the sulphidation of a single grain. Distinction is made between two situations, i.e. the formation of a non-porous and the formation of a porous layer of sulphided limestone. When a nonporous product layer is formed (left-hand side of Fig. 15), the following steps can be distinguished (Heesink et al., 1993).
- Adsorption of the $\mathrm{H}_{2} \mathrm{~S}$ (or COS) at the surface of the product layer as well as desorption of the produced $\mathrm{H}_{2} \mathrm{O}$ (or $\mathrm{CO}_{2}$ ):

$$
\begin{aligned}
& \mathrm{H}_{2} \mathrm{~S}_{(\mathrm{gas})} / \mathrm{COS}_{(\mathrm{gas})} \rightarrow \mathrm{H}_{2} \mathrm{~S}_{(\mathrm{ads})} / \mathrm{COS}_{\text {(ads) }} \\
& \mathrm{H}_{2} \mathrm{O}_{(\mathrm{ads})} / \mathrm{CO}_{2 \text { (ads) }} \rightarrow \mathrm{H}_{2} \mathrm{O}_{(\mathrm{gas})} / \mathrm{CO}_{2 \text { (gas) }}
\end{aligned}
$$

- Reaction of adsorbed $\mathrm{H}_{2} \mathrm{~S}$ (or COS) with $\mathrm{O}^{2-}$ ions (delivered by the $\mathrm{CaO}$-core) towards $\mathrm{S}^{2-}$ ions and $\mathrm{H}_{2} \mathrm{O}$ (or $\mathrm{CO}_{2}$ ) according to a socalled grain reaction:

$$
\begin{aligned}
& \mathrm{H}_{2} \mathrm{~S}_{(\mathrm{ads})} / \mathrm{COS}_{(\mathrm{ads})}+\mathrm{O}^{2-} \\
& \quad \rightarrow \mathrm{S}^{2-}+\mathrm{H}_{2} \mathrm{O}_{(\mathrm{ads})} / \mathrm{CO}_{2(\mathrm{ads})} .
\end{aligned}
$$

- Counterdiffusion of the $\mathrm{S}^{2-}$ and $\mathrm{O}^{2-}$ ions through the product layer.

- Reaction of the $\mathrm{S}^{2-}$ ions with $\mathrm{CaO}$ towards $\mathrm{CaS}$ and $\mathrm{O}^{2-}$ at the core surface (core reaction):

$$
\mathrm{S}^{2-}+\mathrm{CaO} \rightarrow \mathrm{CaS}+\mathrm{O}^{2-} \text {. }
$$

In principle, each step may influence the overall sulphidation rate. However, as sulphidation is performed at relatively high temperatures it is reasonable to assume that the various adsorption and desorption steps proceed relatively fast as compared to the other steps and therefore are not rate determining. Thus, when a non-porous product layer is formed three extremes can be distinguished (Heesink et al., 1993).

1. Grain reaction limitation. The conversion rate of a grain is then given by

$$
\frac{\mathrm{d} X}{\mathrm{~d} t}=\frac{3 k_{g} C^{n}}{N_{\mathrm{o}} R_{\mathrm{0}}}(1+K X)^{2 / 3}
$$

where $K$ represents the expansion factor defined as

$$
K=N_{0}\left(V_{\text {sol, prod }}-V_{\text {sol, reac }}\right)
$$

with $V_{\text {sol, prod }}$ and $V_{\text {sol, reac }}$ representing the molar volumes of the solid product (i.e. $2.76 \times 10^{-5} \mathrm{~m}^{3} \mathrm{~mol}^{-1}$ for $\mathrm{CaS}$ ) and the solid reactant (i.e. $1.67 \times 10^{-5} \mathrm{~m}^{3}$ $\mathrm{mol}^{-1}$ for $\mathrm{CaO}$ ), respectively.

2. Solid state product layer diffusion limitation, with

$$
\frac{\mathrm{d} X}{\mathrm{~d} t}=\frac{3 D_{s} C^{n}}{N_{0} R_{0}^{2}\left[1 /(1-X)^{1 / 3}-1 /(1+K X)^{1 / 3}\right]}
$$

3. Core reaction limitation, with

$$
\frac{\mathrm{d} X}{\mathrm{~d} t}=\frac{3 k_{\mathrm{c}} C^{n}}{N_{0} R_{0}}(1-X)^{2 / 3} .
$$

Both core and grain reaction may well be first order in the adsorbed reactants (either $\mathrm{H}_{2} \mathrm{~S}$ or COS). Furthermore, the rate of product layer diffusion by definition is proportional to the concentration of the adsorbed reactants at the grain surface. Note, however, that the dimensions of the reaction rate constants $k_{g}$ and $k_{c}$ as well as the product layer diffusivity $D_{s}$ depend on the value of the reaction order $n$ which is defined on the basis of the concentration of the reactants in gaseous form. 


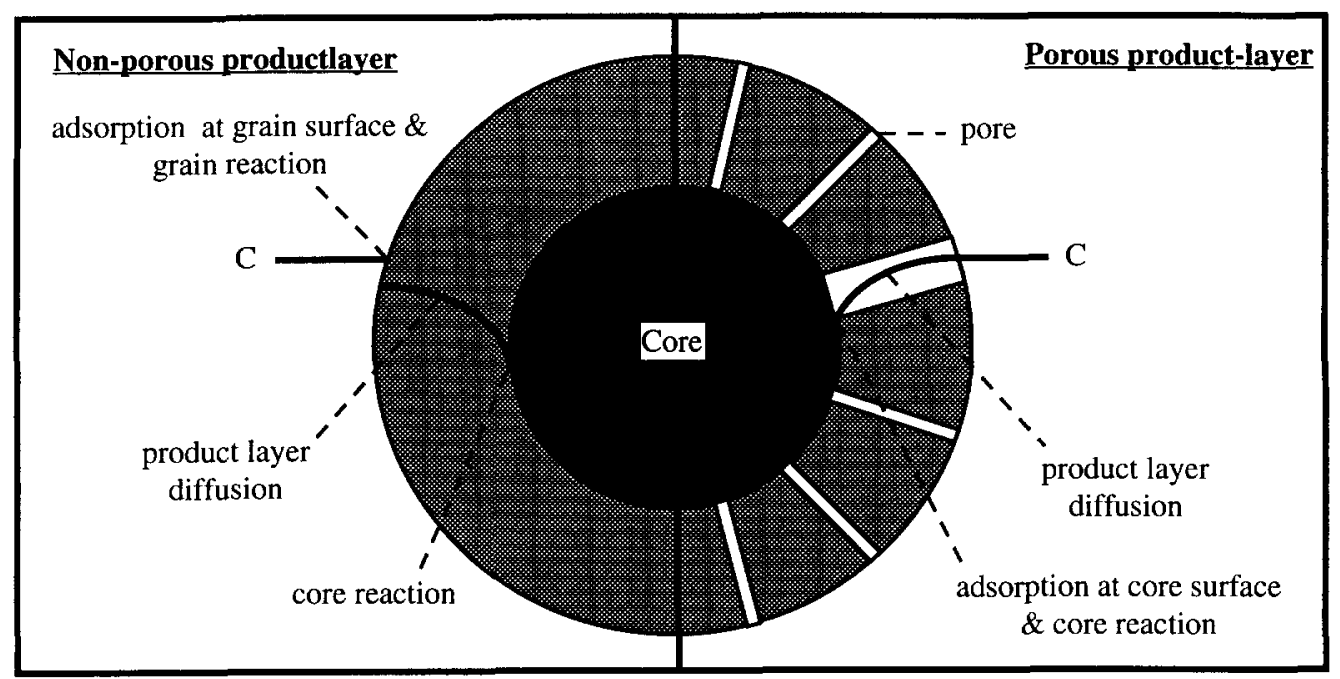

Fig. 15. Schematic representation of a grain and the shrinking core mechanism by which it is converted. Left-hand side: in case a non-porous product layer is formed. Right-hand side: in case a porous product layer is formed.

When a porous product layer is formed (right-hand side of Fig. 15), two parallel reaction routes can be distinguished. The first route is the one already described for a non-porous product layer. The second route comprises of the following steps.

- Gaseous counterdiffusion of $\mathrm{H}_{2} \mathrm{~S}$ (or COS), on the one hand, and $\mathrm{H}_{2} \mathrm{O}$ (or $\mathrm{CO}_{2}$ ) on the other hand through the pores in the product layer.

- Adsorption of $\mathrm{H}_{2} \mathrm{~S}$ (or COS) at the surface of the $\mathrm{CaO}$-core as well as desorption of the produced $\mathrm{H}_{2} \mathrm{O}$ (or $\mathrm{CO}_{2}$ ):

$$
\begin{aligned}
& \mathrm{H}_{2} \mathrm{~S}_{(\mathrm{gas})} / \mathrm{COS}_{(\mathrm{gas})} \rightarrow \mathrm{H}_{2} \mathrm{~S}_{(\mathrm{ads})} / \mathrm{COS}_{\text {(ads) }} \\
& \mathrm{H}_{2} \mathrm{O}_{(\mathrm{ads})} / \mathrm{CO}_{2 \text { (ads) }} \rightarrow \mathrm{H}_{2} \mathrm{O}_{(\mathrm{gas})} / \mathrm{CO}_{2 \text { (gas) }} .
\end{aligned}
$$

- Core reaction of the adsorbed $\mathrm{H}_{2} \mathrm{~S}$ (or COS) with $\mathrm{CaO}$ towards $\mathrm{CaS}$ and $\mathrm{H}_{2} \mathrm{O}$ (or $\mathrm{CO}_{2}$ ):

$$
\begin{gathered}
\mathrm{H}_{2} \mathrm{~S} / \mathrm{COS}_{(\mathrm{ads})}+\mathrm{CaO} \rightarrow \mathrm{CaS} \\
+\mathrm{H}_{2} \mathrm{O} / \mathrm{CO}_{2 \text { (ads) }} .
\end{gathered}
$$

Most of the $\mathrm{H}_{2} \mathrm{~S}$ or $\mathrm{COS}$ presumably passes the product layer in gaseous form according to the second route. The permeability of the pores through the product layer is much higher than that of the solid CaS-lattice; the respective diffusivities typically range from $10^{-7}$ to $10^{-5} \mathrm{~m}^{2} \mathrm{~s}^{-1}$ for the pores and from $10^{-10}$ to $10^{-15} \mathrm{~m}^{2} \mathrm{~s}^{-1}$ for the solid lattice. Even when no more than $1 \%$ of the product layer were porous, the transport through the pores would outweigh the transport through the solid matrix. It is therefore concluded that the route through the pores is the only route of interest. Once again assuming that the adsorption and desorption steps are not limiting, only two extremes can be distinguished when a porous product layer is formed, i.e. product layer diffusion limitation and core reaction limitation.

\subsection{The grain size distribution model}

According to the GSD model a porous particle consists of spherical grains with various sizes. The size distribution of the grains is derived from the pore size distribution which is measured by mercury porosimetry. It is assumed that the radius of a pore is proportional to the radius of the grains that surround this pore. A pore-to-sphere factor $F$ is defined as the ratio of the respective radii of grains and pores. The mercury porosigram is divided into a number of pore size classes. The relative contribution of pores from a certain pore size class to the porosity of a solid is assumed to be equal to the weight fraction of grains from the corresponding grain size class (having a radius of $F$ times the relevant pore radius). $F$ is determined from the mercury porosigram under consideration and typically adapts values between 1 and 2. A single value is used for all size classes. Once the grain size distribution has been determined, the conversion behaviour is calculated for each grain size class by one of the equations (2), (4) or (5). Finally, the overall conversion extent of a solid is obtained by weighed averaging of the conversion extents calculated for the various grain size classes. For more detailed information about the GSD model, refer to Heesink et al. (1993).

The GSD model was applied to simulate measured conversion behaviour in order to determine the sulphidation mechanism. Calculations were based on the mercury porosigram of Fig. 2. This porosigram was divided into 38 size fractions, the smallest pores having a radius of $8 \mathrm{~nm}$ and the largest having a radius of $102 \mathrm{~nm}$. Pores with radii larger than $102 \mathrm{~nm}$ were regarded as macropores surrounding clusters of grains rather than grains. Anyhow, the surface area (and thus reactivity) ascribable to these large pores is negligible; see Fig. 2. The pore-to-sphere factor was calculated to be 1.56 . 
Although the phenomenon of pore plugging is included in the GSD model, none of the simulations indicated that pore plugging would occur. This corresponds to the experimental results showing that complete sulphidation can be obtained.

\subsection{Sulphidation with $\mathrm{H}_{2} \mathrm{~S}$}

The reaction order in $\mathrm{H}_{2} \mathrm{~S}$ was found to be 0.5 at all applied temperatures and $\mathrm{H}_{2} \mathrm{~S}$-pressures. This value differs from the value of unity that was reported by Westmoreland et al. (1977), who performed TGA measurements at temperatures between 300 and $800^{\circ} \mathrm{C}$. However, it is very likely that the measurements of Westmoreland $e t$ al. were affected by mass transfer limitation. These investigators measured the extremely low activation energy of $22 \mathrm{~kJ} \mathrm{~mol}^{-1}$ indicating that external mass transfer might have been rate determining during their experiments. Though they varied the gas velocity through the TGA and observed no significant influence on conversion behaviour, the possibility of external mass transport limitation may not be excluded (Wigmans et al., 1983). Better agreement exists with the results of Pell (1971) who examined the suphidation of fully calcined dolomite powder in a TGA. By elaborating the data that Pell obtained at different $\mathrm{H}_{2} \mathrm{~S}$-pressures, reaction orders of 0.9 and 0.5 were found for temperatures of 700 and $625^{\circ} \mathrm{C}$, respectively. The data obtained by Pell at $700^{\circ} \mathrm{C}$ may have been affected by mass transfer limitation as rather large samples $(50-150 \mathrm{mg})$ were applied.

The activation energy of the reaction between $\mathrm{H}_{2} \mathrm{~S}$ and calcined limestone was determined at $160 \mathrm{~kJ} \mathrm{~mol}^{-1}$. This value is much higher than the value of $22 \mathrm{~kJ} \mathrm{~mol}^{-1}$ reported by Westmoreland et al. (1977). However, as stated before, the measurements of Westmoreland et al. were probably affected by mass transfer limitation. Borgwardt et al. (1984) measured an activation energy of $130 \mathrm{~kJ} \mathrm{~mol}^{-1}$. However, before sulphidation was performed, Borgwardt et al. first sintered the calcined limestone samples for $30 \mathrm{~min}$ at $950^{\circ} \mathrm{C}$. Such treatment may have affected the intrinsic reactivity of the limestone and therefore could explain the difference in activation energy. Our result compares better with the value of $155 \mathrm{~kJ} \mathrm{~mol}^{-1}$ reported by Attar and Dupuis (1979), and the values that can be derived from the results obtained by Abbasian et al. (1991), i.e. $168 \mathrm{~kJ} \mathrm{~mol}^{-1}$ for calcined limestone and $177 \mathrm{~kJ} \mathrm{~mol}^{-1}$ for fully calcined dolomite.

In order to establish the mechanism of sulphidation, it was tried to simulate measured conversion vs time behaviour with the GSD model. While doing so, only the extreme cases of core reaction limitation, product layer diffusion limitation and grain reaction limitation were considered. Figure 16 shows the agreement between measured and simulated behaviour for the experiments performed at a $\mathrm{H}_{2} \mathrm{~S}$-pressure of $2000 \mathrm{~Pa}$ and temperatures of 500,600 and $700^{\circ} \mathrm{C}$, respectively. The conversion extent that was calculated on assuming core reaction limitation had to
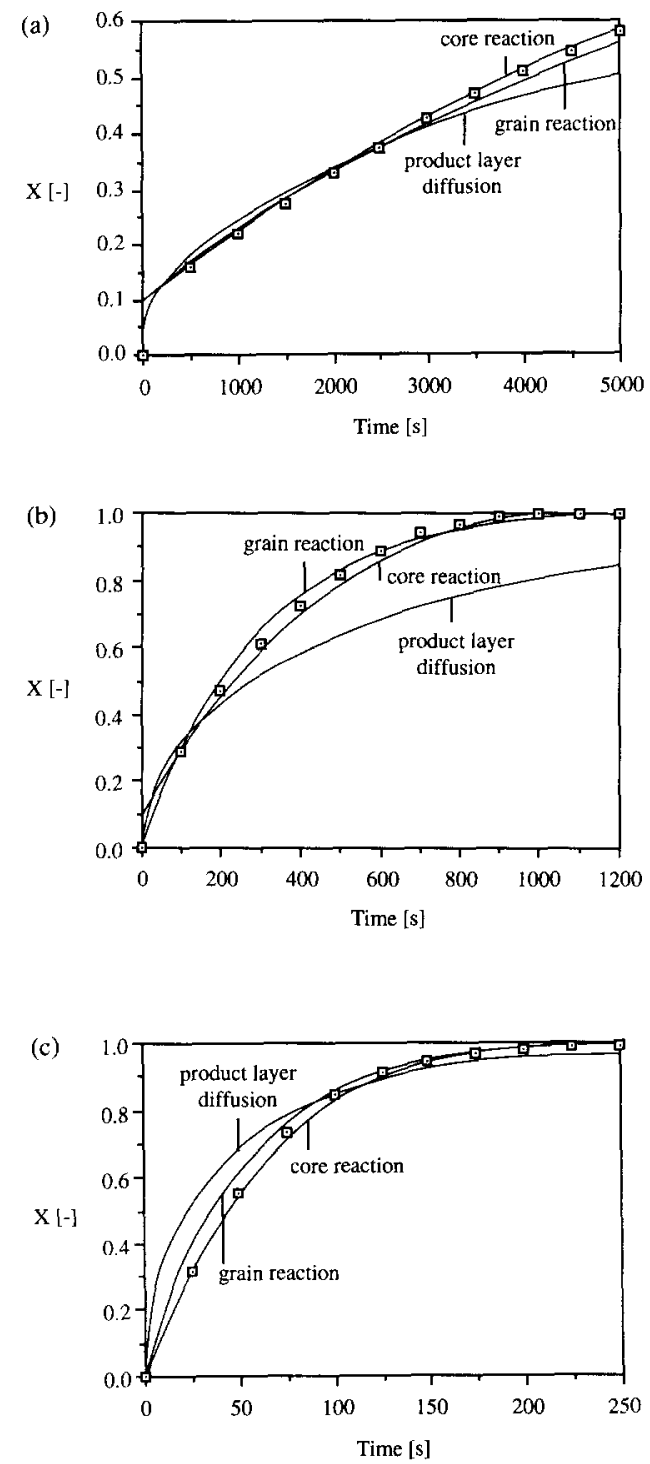

Fig. 16. GSD-model predictions together with experimental data obtained during sulphidation with $\mathrm{H}_{2} \mathrm{~S}(2000 \mathrm{~Pa})$ : (a) $T=500^{\circ} \mathrm{C}, k_{\mathrm{c}}=2.3 \times 10^{-7} \mathrm{~mol}^{0.5} \mathrm{~m}^{-0.5} \mathrm{~s}^{-1}, D_{\mathrm{s}}=1.7 \times$ $10^{-15} \mathrm{~mol}^{0.5} \mathrm{~m}^{0.5} \mathrm{~s}^{-1}, \quad k_{q}=4.2 \times 10^{-7} \mathrm{~mol}^{0.5} \mathrm{~m}^{-0.5} \mathrm{~s}^{-1} ; \quad$ (b) $T=600^{\circ} \mathrm{C}, \quad k_{\mathrm{c}}=4.0 \times 10^{-6} \mathrm{~mol}^{0.5} \mathrm{~m}^{-0.5} \mathrm{~s}^{-1}, \quad D_{\mathrm{s}}=3.2 \times$ $10^{-14} \mathrm{~mol}^{0.5} \mathrm{~m}^{0.5} \mathrm{~s}^{-1}, k_{\mathrm{g}}=1.3 \times 10^{-5} \mathrm{~mol}^{0.5} \mathrm{~m}^{-0.5} \mathrm{~s}^{-1}$; (c) $T=700^{\circ} \mathrm{C}, \quad k_{\mathrm{c}}=3.0 \times 10^{-5} \mathrm{~mol}^{0.5} \mathrm{~m}^{-0.5} \mathrm{~s}^{-1}, \quad D_{s}=4.0 \times$ $10^{-13} \mathrm{~mol}^{0.5} \mathrm{~m}^{0.5} \mathrm{~s}^{-1}, k_{g}=7.5 \times 10^{-5} \mathrm{~mol}^{0.5} \mathrm{~m}^{-0.5} \mathrm{~s}^{-1}$.

be increased by 0.1 to obtain good fits for the experiments performed at 500 and $600^{\circ} \mathrm{C}$ [Figs $16(\mathrm{a})$ and (b)]. This was also necessary when assuming grain reaction limitation at $500^{\circ} \mathrm{C}$ [Fig. 16(a)]. A plausible explanation for this necessity can only be given in case of core reaction limitation; see later on. All together 20 conversion vs time curves, which were obtained at various $\mathrm{H}_{2} \mathrm{~S}$-pressures and temperatures, were simulated with the GSD model. Overall, the best fits were obtained on assuming core reaction limitation. The best-fit values of the core reaction rate constant $k_{c}$ (at the applied $\mathrm{H}_{2}$-pressure of $4000 \mathrm{~Pa}$ ) obey the 
following equation (within 10\%):

$$
k_{c}=5946 \exp \left(-\frac{154,000}{R T}\right) \mathrm{mol}^{0.5} \mathrm{~m}^{-0.5} \mathrm{~s}^{-1} \text {. }
$$

The activation energy resulting from the simulations amounts to $154 \mathrm{~kJ} \mathrm{~mol}^{-1}$ and agrees reasonably well with the value of $160 \mathrm{~kJ} \mathrm{~mol}^{-1}$ which was derived from Fig. 7.

Our conclusion that some reaction at the core surface most probably determines the rate of sulphidation differs from the conclusion of Borgwardt et al. (1984) stating that product layer diffusion is rate determining. Borgwardt et al. came to their conclusion by examining the influence of surface area, $A$, on the rate of sulphidation. They prepared calcined limestone samples with different specific surface areas by means of controlled sintering. From the relationship

$$
A=\frac{3}{\rho_{\text {sol, reac }} R_{0}}
$$

it follows that the initial radius of the grains, $R_{0}$, within a certain sample can be derived from $A$, higher values of $A$ corresponding to lower values of $R_{0}$. The samples thus obtained were sulphided under equal conditions. According to the grain model, the time needed to reach a certain conversion extent $X$, here denoted as $t(X)$, is a function of $R_{0}$. In case of core reaction limitation, $t(X)$ is proportional to $R_{0}$ [see eq. (5)]. However, when product layer diffusion is limiting, $t(X)$ is proportional to $R_{0}^{2}$ [see eq. (4)]. Borgwardt et al. measured the time needed to obtain a conversion extent of $70 \%$ and found that this time was proportional to $R_{0}^{2.4}$. Based on this result they concluded that product layer diffusion is the limiting step in the sulphidation mechanism. In deriving this conclusion they implicitly assumed that sintering did not affect the reactivity at the core surface. However, it is quite well possible that this reactivity drops during sintering as the number of dislocations in the CaO-lattice most probably diminishes during heat treatment. From material sciences it is known that the presence of dislocations increases reactivity. In fact, Borgwardt et al. (1984) arrived at a similar conclusion as they found that their best-fit values of $D_{s}$ were smallest for those samples that were sintered longest: a more ideal $\mathrm{CaO}$-lattice was supposed to result in the formation of a more ideal (and therefore less permeable) CaS-lattice during sulphidation. When the value of the core reaction rate constant $k_{c}$ indeed decreases during sintering, $t(X)$ will be proportional to $R_{0}^{x}$, with $x$ being greater than unity even in the case of core reaction limitation. Therefore, $x$ being 2.4 is no guarantee that product layer diffusion is the limiting step in the sulphidation mechanism.

The bare fact that some core reaction seems to determine the rate of sulphidation does not yield information to the question whether the product layer is porous or not. When a non-porous layer is formed reaction (R9) might be the limiting step in the sulphidation mechanism. However, reaction (R 10) might be rate determining if a porous layer is formed. By examining the adsorption of $\mathrm{H}_{2} \mathrm{~S}$ on sulphided limestone, Heesink and van Swaaij (1995) conclude that the layer of sulphided limestone remains porous during conversion. Porosity may be maintained by a continuous process of crack formation.

Based upon our results the following sulphidation mechanism is now proposed. During the initial stage of sulphidation a certain amount of $\mathrm{H}_{2} \mathrm{~S}$ is rapidly converted at the fresh (and uncovered) $\mathrm{CaO}$-surface resulting in the registration of a relatively large weight increase by the TGA. With the reaction order in $\mathrm{H}_{2} \mathrm{~S}$ being 0.5 , one might suggest that dissociative adsorption precedes reaction, possible fragments being $\mathrm{H}$ and HS (Anderson, 1971). In fact, Pell (1971) also suggested the existence of an adsorbed $\mathrm{H}_{2} \mathrm{~S}$-layer. However, Pell regarded this layer to be a barrier for further sulphidation which can only be passed at higher temperature. Here it is suggested that this layer is some kind of lock chamber that the $\mathrm{H}_{2} \mathrm{~S}$-molecules have to pass before they can react. As conversion proceeds the $\mathrm{CaO}$-surface becomes covered by a porous product layer. As a consequence $\mathrm{H}_{2} \mathrm{~S}$ can only react at those places where the $\mathrm{CaO}$ is not covered by sulphided material. This implies that the sulphidation rate per $\mathrm{m}^{2}$ of core surface drops once a product layer has been formed. Since this drop is most clearly observed at lower temperatures it is assumed that the porosity of the product layer (and thus the fraction of core surface available for reaction) increases with temperature. This agrees with the conclusions of Duo et al. (1994), who examined product layer formation on the basis of crystal growth thermodynamics. It should be noted that the value of $k_{c}$ as delivered by eq. (6) refers to the sulphidation rate once a product layer has been formed. Since a single value of $k_{c}$ can be used to calculate the rate of sulphidation over a wide range of conversion, it is concluded that the porosity of the product layer remains practically constant after the first stage of sulphidation. The above theory also explains the necessity to adjust the initial conversion extent in order to obtain good GSD-fits when assuming core reaction limitation: the initial reaction rate per $\mathrm{m}^{2}$ of core surface is higher than the constant rate which remains when the core surface is partly covered with a product layer. This explanation is not valid in case of grain reaction limitation, making it more likely that the rate of sulphidation is governed by some core reaction and not by a grain reaction.

Our finding that $\mathrm{H}_{2}$ inhibits the rate of sulphidation agrees with the observations of Borgwardt et al. (1984). Whereas Borgwardt et al. assumed that the permeability of the solid product layer is reduced by the penetration of $\mathrm{H}_{2}$-molecules into this layer, we believe that co-adsorption of $\mathrm{H}_{2}$ on the $\mathrm{CaO}$ surface may cause the inhibiting effect. We presume that the inhibiting effect of $\mathrm{CO}$ on sulphidation also is the consequence of competitive co-adsorption at the $\mathrm{CaO}$-surface. Like $\mathrm{H}_{2} \mathrm{~S}, \mathrm{H}_{2}$ and $\mathrm{CO}$ are assumed to 
penetrate through the porous product layer by gaseous diffusion and to be adsorbed by the CaO-surface.

\subsection{Sulphidation with $\mathrm{COS}$}

The reaction order in COS was determined at 0.18 for a sulphidation temperature of $600^{\circ} \mathrm{C}$ and at 0.32 for a temperature of $650^{\circ} \mathrm{C}$. The observed dependency of the reaction order on temperature is probably caused by adsorption phenomena. Yang and Chen (1979) also examined the reaction between COS and calcined limestone and measured a reaction order of unity in $\operatorname{COS}$ at a temperature of $800^{\circ} \mathrm{C}$. However, these investigators reported the extremely low activation energy of $18 \mathrm{~kJ} \mathrm{~mol}^{-1}$ indicating that their TGAmeasurements were probably affected by mass transfer limitation. This is quite well possible considering the large samples of about $50 \mathrm{mg}$ that were applied.

The fact that the reaction order in COS depends on temperature implies that the activation energy varies with COS-pressure. Borgwardt et al. (1984) measured an activation energy of $130 \mathrm{~kJ} \mathrm{~mol}^{-1}$ at a COS-pressure of $430 \mathrm{~Pa}$ and temperatures ranging from 600 to $900^{\circ} \mathrm{C}$. From our results (see Fig. 10) an activation energy of about $125 \mathrm{~kJ} \mathrm{~mol}^{-1}$ can be derived for the same COS-pressure. When correction is made for the temperature dependency of the reaction order a value of $200 \mathrm{~kJ} \mathrm{~mol}^{-1}$ is obtained for the activation energy as defined by eq. (1).

The mechanism of the reaction between calcined limestone and COS was investigated by means of the GSD model. Figure 17 shows the results. When assuming that some core or grain reaction is rate determining the calculated conversion extent had to be increased by 0.13 , respectively, 0.1 to obtain good fits of the runs performed at 600 and $650^{\circ} \mathrm{C}$. Again some reaction at the core surface seems to limit the rate of sulphidation. The best-fit values of $k_{c}$, as obtained by simulating five runs at each temperature, obey the following equation:

$$
k_{c}=6.35 \times 10^{5} \exp \left(-\frac{200,000}{R T}\right) \mathrm{mol}^{1-n} \mathrm{~m}^{3 n-2} \mathrm{~s}^{-1}
$$

with $n$ being 0.18 and 0.32 at 600 and $650^{\circ} \mathrm{C}$, respectively. The activation energy that follows from the simulations amounts to $200 \mathrm{~kJ} \mathrm{~mol}^{-1}$ and corresponds to the value directly obtained from measurements. The mechanism as described above for the sulphidation with $\mathrm{H}_{2} \mathrm{~S}$ may also be valid when sulphidation is carried out with COS. Initially, a certain amount of COS is rapidly adsorbed and converted at the fresh $\mathrm{CaO}$-surface. Once a porous product layer has been formed part of the $\mathrm{CaO}$-surface becomes covered and the rate of sulphidation drops. The value of $k_{c}$ as delivered by eq. (8) refers to this lower rate of reaction.

The conversion vs time curves obtained at $700^{\circ} \mathrm{C}$ and COS-pressures above about $2000 \mathrm{~Pa}$ show a certain overshoot in conversion (see Fig. 11). This overshoot vanishes in time resulting in a conversion extent
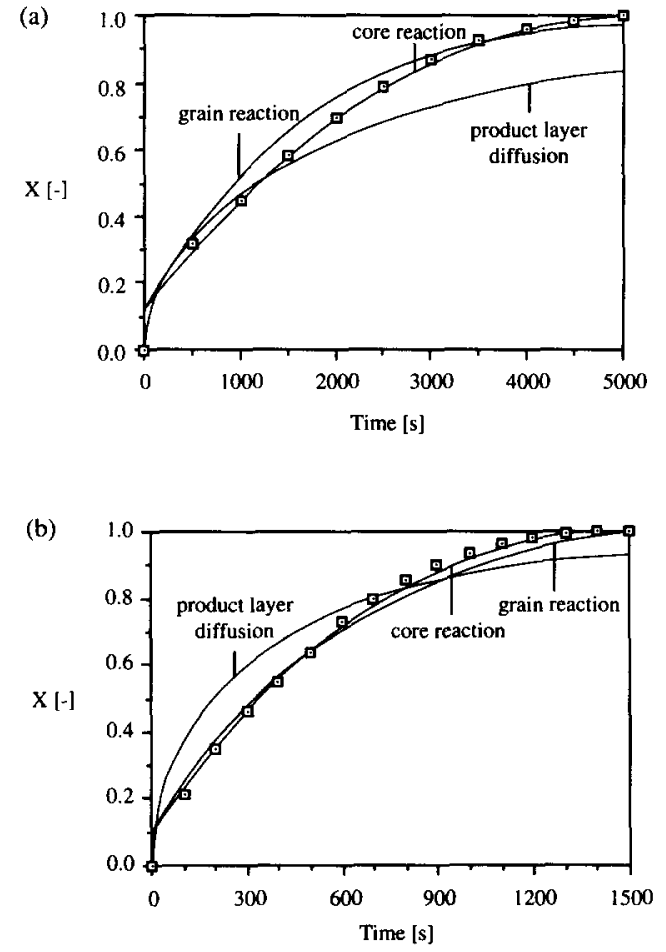

Fig. 17. GSD-model predictions together with experimental data obtained during sulphidation with $\operatorname{COS}(700 \mathrm{~Pa})$ : (a) $T=600^{\circ} \mathrm{C}, k_{c}=6.5 \times 10^{-7} \mathrm{~mol}^{0.82} \mathrm{~m}^{-1.46} \mathrm{~s}^{-1}, D_{s}=6.0 \times$ $10^{-15} \mathrm{~mol}^{0.82} \mathrm{~m}^{-0.46} \mathrm{~s}^{-1}, \quad k_{\mathrm{g}}=2.1 \times 10^{-6} \mathrm{~mol}^{0.82}$ $\mathrm{m}^{-1.46} \mathrm{~s}^{-1} ;$ (b) $T=650^{\circ} \mathrm{C}, k_{\mathrm{c}}=2.9 \times 10^{-6} \mathrm{~mol}^{0.68} \mathrm{~m}^{-1.04}$ $\mathrm{s}^{-1}, D_{\mathrm{s}}=5.0 \times 10^{-14} \mathrm{~mol}^{0.68} \mathrm{~m}^{-0.04} \mathrm{~s}^{-1}, k_{g}=6.5 \times 10^{-6}$ $\mathrm{mol}^{0.68} \mathrm{~m}^{-1.04} \mathrm{~s}^{-1}$

of $100 \%$ at the end of each experiment. The described phenomenon suggests that some intermediate product is formed which has a higher molecular weight that $\mathrm{CaS}$ and which is able to react with $\mathrm{COS}$ towards $\mathrm{CaS}$. We believe that $\mathrm{CaCO}_{3}$ is that intermediate. It may be formed according to the following side reaction:

$$
\begin{gathered}
\mathrm{CaO}+2 \mathrm{COS} \rightarrow \mathrm{CaCO}_{3}+\mathrm{CS}_{2} \\
\text { with } K_{\text {eq }}=10.45 \text { at } 700^{\circ} \mathrm{C} .
\end{gathered}
$$

The produced $\mathrm{CaCO}_{3}$ may either be calcined towards $\mathrm{CaO}$, which then reacts towards $\mathrm{CaS}$, or directly react with COS towards CaS. To get a better insight the following test was performed (see Fig. 18). First a calcined limestone sample was sulphided with COS at a temperature of $750^{\circ} \mathrm{C}$ and a COS-pressure of $2280 \mathrm{~Pa}$ in the usual way. At the time that the maximum extent of conversion (i.e. $120 \%$ ) was reached, the COS supply was stopped (while keeping all other conditions constant) to see whether possibly formed $\mathrm{CaCO}_{3}$ would calcine. This was hardly the case (see curve $B$ in Fig. 18). Then the supply of COS was restarted yielding curve $A$ (shifted to the left in Fig. 18) which is similar to the curves depicted in Fig. 11. Another sample was then sulphided at equal conditions. Again the COS-supply was stopped at the time that the maximum conversion extent was reached. 


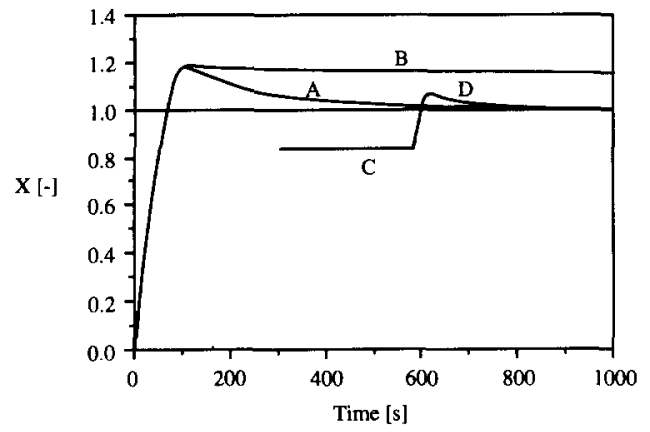

Fig. 18. Conversion vs time behaviour during sulphidation with $\operatorname{COS}$ at $750^{\circ} \mathrm{C}$ and a COS-pressure of $2280 \mathrm{~Pa}$ : (a) normal run; (b) after stopping the COS-supply; (c) after stopping the COS-supply and subsequent heat treatment at

$850^{\circ} \mathrm{C}$; (d) like $\mathrm{C}$ after re-starting the COS-supply.

Then the temperature was raised to $850^{\circ} \mathrm{C}$. This time a decrease in weight was observed. The real extent of sulphidation (corresponding to the weight remaining after calcination) is given by $\mathrm{C}$. After the weight signal had stabilized, the COS-supply was restarted. This resulted in curve $\mathrm{D}$ which, like the curves depicted by Fig. 11, shows an overshoot in conversion. Apparently, the product formed during the heat treatment at $850^{\circ} \mathrm{C}$ shows the same sulphidation behaviour than calcined limestone (i.e. $\mathrm{CaO}$ ). The obtained results support the theory that $\mathrm{CaCO}_{3}$ is formed when calcined limestone is sulphided with $\mathrm{COS}$. This $\mathrm{CaCO}_{3}$ can obviously be calcined towards $\mathrm{CaO}$ at a temperatures of $850^{\circ} \mathrm{C}$ (or above) but not at temperatures of $750^{\circ} \mathrm{C}$ or below. The gradual vanishing of the overshoot in conversion extent observed during sulphidation at temperatures of $750^{\circ} \mathrm{C}$ or below is therefore thought to be caused by the reaction between $\mathrm{CaCO}_{3}$ and COS:

$$
\begin{gathered}
\mathrm{CaCO}_{3}+\mathrm{COS} \rightarrow \mathrm{CaS}+2 \mathrm{CO}_{2} \\
\text { with } K_{\text {eq }}=3072 \text { at } 700^{\circ} \mathrm{C} .
\end{gathered}
$$

Though reaction ( $\mathrm{R} 11)$ may also proceed at lower temperatures and/or lower COS-pressures, it only causes an overshoot at temperatures of $700^{\circ} \mathrm{C}$ or higher and at COS-pressures above about $2000 \mathrm{~Pa}$. This indicates that the rate of $\mathrm{CaCO}_{3}$-formation [according to reaction (R11)] is more dependent on temperature and/or COS-pressure than the rate by which $\mathrm{CaCO}_{3}$ is converted towards $\mathrm{CaS}$ [according to reaction (R12)]. As far as the dependency on COS-pressure concerns, this agrees with the fact that two COSmolecules are involved in reaction (R11), whereas only one COS-molecule is involved in reaction (R12).

\subsection{Sulphidation with mixtures of $\mathrm{H}_{2} \mathrm{~S}$ and $\mathrm{COS}$}

The addition of a small amount of COS to a $\mathrm{H}_{2} \mathrm{~S}$ containing gas mixture was found to have a strong inhibiting effect on the sulphidation rate attainable with that gas mixture. To get a better understanding of this remarkable phenomenon, conversion vs time behaviour observed with $\mathrm{H}_{2} \mathrm{~S}$ alone and with mixtures of $\mathrm{H}_{2} \mathrm{~S}$ and $\mathrm{COS}$ was simulated with the GSD model. Figure 19 shows a typical result. As to be expected on the basis of the above findings, the sulphidation behaviour obtained when solely $\mathrm{H}_{2} \mathrm{~S}$ is applied can be best described assuming core reaction limitation. The $k_{c}$ value that was used to obtain the core reaction limitation fit in Fig. 19(a) is about $60 \%$ higher than the value predicted by eq. (6) which was derived from earlier sulphidation experiments. A possible explanation for this discrepancy may be that the calcined limestone samples that were applied to investigate sulphidation behaviour with mixtures of $\mathrm{H}_{2} \mathrm{~S}$ and $\operatorname{COS}$ were much older than those applied for former experiments. Some process might have affected the reactivity of these samples during storage (about 3 months from calcination). Apart from this, the result of Fig. 19(b) is quite remarkable. Not only the sulphidation rate drops when COS is added, but apparently also the sulphidation mechanism changes: whereas some core reaction was found to be rate determining when sulphidation is carried out with either $\mathrm{H}_{2} \mathrm{~S}$ or COS, product layer diffusion appears to be rate determining when a mixture of $\mathrm{H}_{2} \mathrm{~S}$ and $\mathrm{COS}$ is applied. The formation of $\mathrm{CaCO}_{3}$, which is induced by the presence of COS according to reaction (R11), is
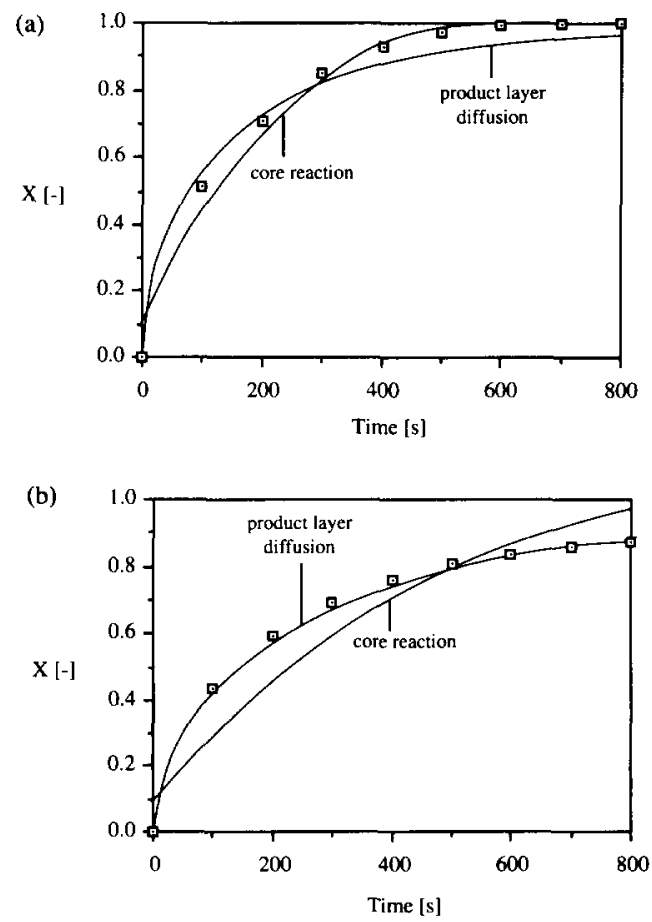

Fig. 19. GSD-model predictions together with experimental data obtained during sulphidation at $600^{\circ} \mathrm{C}$ : (a) with $\mathrm{H}_{2} \mathrm{~S}$ only $(2670 \mathrm{~Pa}), k_{\mathrm{c}}=6.5 \times 10^{-6} \mathrm{~mol}^{0.5} \mathrm{~m}^{-0.5} \mathrm{~s}^{-1}, D_{\mathrm{s}}=9.8$ $\times 10^{-14} \mathrm{~mol}^{0.5} \mathrm{~m}^{0.5} \mathrm{~s}^{-1}$; (b) with $\mathrm{H}_{2} \mathrm{~S}(2670 \mathrm{~Pa})$ and $\mathrm{COS}$ $(170 \mathrm{~Pa}), k_{c}=3.5 \times 10^{-6} \mathrm{~mol}^{0.5} \mathrm{~m}^{-0.5} \mathrm{~s}^{-1}, D_{s}=5.0 \times 10^{-14}$ 
thought to play a role in this. $\mathrm{CaCO}_{3}$ not only has a larger molecular volume than CaS $\left(3.69 \times 10^{-5}\right.$ vs $2.76 \times 10^{-5} \mathrm{~m}^{3} \mathrm{~mol}^{-1}$ for CaS) but also is more susceptible to sintering because of its relatively low melting temperature $\left(1340^{\circ} \mathrm{C}\right.$ vs $2450^{\circ} \mathrm{C}$ for $\left.\mathrm{CaS}\right)$. Although no $\mathrm{CaCO}_{3}$ remains after complete conversion because it reacts with $\mathrm{COS}$ or $\mathrm{H}_{2} \mathrm{~S}$ towards $\mathrm{CaS}$, its temporary presence may reduce the permeability of the product layer by contributing to the formation of bridges between pieces of material that are separated by small gaps or pores. In this way, product layer diffusion may become the rate determining step in the sulphidation mechanism. The fact that some core reaction and not product layer diffusion was found to be rate determining when sulphidation is performed with $\mathrm{COS}$ only (though $\mathrm{CaCO}_{3}$ is also formed then) might indicate that the sintering of $\mathrm{CaCO}_{3}$ is enhanced by the presence of $\mathrm{H}_{2} \mathrm{~S}$ as was suggested by Illerup et al. (1993). Another explanation for this apparent discrepancy is obtained when the reaction rates of $\mathrm{H}_{2} \mathrm{~S}$ and COS are compared. For a temperature of $600^{\circ} \mathrm{C}$ eqs (6) and (8) deliver $k_{c}$-values of $3.6 \times 10^{-6} \mathrm{~mol}^{0.5} \mathrm{~m}^{-0.5}$ $\mathrm{s}^{-1}$ and $6.9 \times 10^{-7} \mathrm{~mol}^{0.82} \mathrm{~m}^{-1.46} \mathrm{~s}^{-1}$ for $\mathrm{H}_{2} \mathrm{~S}$ and $\mathrm{COS}$, respectively. $\mathrm{H}_{2} \mathrm{~S}$ thus reacts faster than COS. Therefore, at equal product layer permeability, core reaction limitation can be observed when sulphidation is carried out with COS, whereas product layer diffusion limitation is observed when sulphidation is carried out with $\mathrm{H}_{2} \mathrm{~S}$ (or a mixture of $\mathrm{H}_{2} \mathrm{~S}$ and $\mathrm{COS}$ )

\section{CONCLUSIONS}

The sulphidation of calcined limestone with $\mathrm{H}_{2} \mathrm{~S}$, COS and mixtures of $\mathrm{H}_{2} \mathrm{~S}$ and $\mathrm{COS}$ has been studied at temperatures between 500 and $700^{\circ} \mathrm{C}$. The reaction order in $\mathrm{H}_{2} \mathrm{~S}$ was found to be 0.5 at all applied temperatures, whereas the order in COS appeared to be dependent on temperature: 0.18 at $600^{\circ} \mathrm{C}$ and 0.32 at $650^{\circ} \mathrm{C}$. The activation energy of sulphidation was determined at 160 and $200 \mathrm{~kJ} \mathrm{~mol}^{-1}$ for $\mathrm{H}_{2} \mathrm{~S}$ and $\mathrm{COS}$, respectively. It was found that sulphidation with $\mathrm{H}_{2} \mathrm{~S}$ is inhibited by the presence of $\mathrm{COS}, \mathrm{H}_{2}$ and $\mathrm{CO}$. Indications were obtained for the side reaction $\mathrm{CaO}+2 \mathrm{COS} \rightarrow \mathrm{CaCO}_{3}+\mathrm{CS}_{2}$ to proceed when sulphidation is carried out with COS.

The mechanism of sulphidation was investigated by means of the GSD model. From model simulations it appeared that some reaction at the surface of the unreacted $\mathrm{CaO}$-core most probably determines the rate of sulphidation when either $\mathrm{H}_{2} \mathrm{~S}$ or $\mathrm{COS}$ are applied. During the initial stage of sulphidation reaction takes place at the entire $\mathrm{CaO}$-surface. However, as conversion proceeds the $\mathrm{CaO}$-core becomes partly covered by a product layer which is assumed to remain porous. Reaction then only takes place at the uncovered parts of the $\mathrm{CaO}$-surface. The porosity of the product layer and consequently the fraction of $\mathrm{CaO}$-surface available for reaction are assumed to be higher at increasing temperature. Competitive co-adsorption of $\mathrm{H}_{2}$ or $\mathrm{CO}$ at the $\mathrm{CaO}$-surface is believed to cause the inhibiting effect of these compounds on sulphidation.

When sulphidation is carried out with a mixture of $\mathrm{H}_{2} \mathrm{~S}$ and $\mathrm{COS}$, product layer diffusion was found to be rate determining. This change in mechanism is thought to be caused by the formation of $\mathrm{CaCO}_{3}$ (induced by the presence of COS) and the subsequent sintering of this $\mathrm{CaCO}_{3}$ which reduces the permeability of the product layer.

Acknowledgements-This investigation was supported by the Directorate-General XII of the European Communities and the Dutch organizations TNO-IMET and NOVEM BV. The authors acknowledge D.W.F. Brilman, H.J. Koele, J. Nijmeijer and A.G. Steghuis for their assistance in the experimental work.

\begin{tabular}{|c|c|}
\hline & NOTATION \\
\hline$A$ & specific surface area, $\mathrm{m}^{2} \mathrm{~kg}^{-1}$ \\
\hline$C$ & $\begin{array}{l}\text { concentration of } \mathrm{H}_{2} \mathrm{~S} \text { and/or } \mathrm{COS} \text { in the ga } \\
\text { bulk, } \mathrm{mol} \mathrm{m}^{-3}\end{array}$ \\
\hline$D_{s}$ & $\begin{array}{l}\text { product layer diffusivity, } \mathrm{mol}^{1-n} \mathrm{~m}^{3 n-} \\
\mathrm{s}^{-1}\end{array}$ \\
\hline$E_{\text {act }}$ & activation energy, $\mathrm{J} \mathrm{mol}^{-1}$ \\
\hline$F$ & pore-to-sphere factor, dimensionless \\
\hline$k_{c}$ & $\begin{array}{l}\text { reaction rate constant of the core reactior } \\
\mathrm{mol}^{1-n} \mathrm{~m}^{3 n-2} \mathrm{~s}^{-1}\end{array}$ \\
\hline$k_{g}$ & $\begin{array}{l}\text { reaction rate constant of the grain reactior } \\
\mathrm{mol}^{1-n} \mathrm{~m}^{3 n-2} \mathrm{~s}^{-1}\end{array}$ \\
\hline$k_{A}$ & Arrhenius constant, $\mathrm{m}^{3 n} \mathrm{~mol}^{-n} \mathrm{~s}^{-1}$ \\
\hline$K$ & expansion factor, dimensionless \\
\hline$K_{\text {eq }}$ & equilibrium constant, dimensionless \\
\hline$n$ & $\begin{array}{l}\text { reaction order in gaseous reactant, dime } \\
\text { sionless }\end{array}$ \\
\hline$N_{0}$ & $\begin{array}{l}\text { initial concentration of solid reactant } \\
\text { grains, } \mathrm{mol} \mathrm{m}^{-3}\end{array}$ \\
\hline$P$ & (partial) pressure, $\mathrm{Pa}$ \\
\hline$R$ & gas constant, $\mathbf{J} \mathrm{mol}^{-1} \mathrm{~K}^{-1}$ \\
\hline$R_{0}$ & initial radius of grain, $m$ \\
\hline$t$ & time, $\mathrm{s}$ \\
\hline$T$ & temperature, $\mathrm{K}$ \\
\hline$X$ & conversion, dimensionless \\
\hline$V_{\text {sol, reac }}$ & $\begin{array}{l}\text { molecular volume of solid reactant, } \mathrm{m}^{3} \\
\mathrm{~mol}^{-1}\end{array}$ \\
\hline$V_{\text {sol, prod }}$ & $\begin{array}{l}\text { molecular volume of solid product, } \mathrm{m}^{3} \\
\mathrm{~mol}^{-1}\end{array}$ \\
\hline
\end{tabular}

Greek letters

$\rho_{\text {sol, reac }}$ density of solid reactant, $\mathrm{kg} \mathrm{m}^{-3}$

\section{REFERENCES}

Abbasian, J., Rue, D. M. and Lau, F. S., 1991, In-bed sulphur capture during pressurized fluidized-bed hydroretorting of eastern oil shales. Fuel 70, 1342-1346.

Abbasian, J., Wangerow, J. R. and Hill, A. H., 1993, Effect of $\mathrm{HCl}$ on sulphidation of calcium oxide. Chem. Engng Sci. 48, 2689-2695.

Anderson, J. R. (Ed.), 1971, Chemisorption and Reactions on Metallic Films, p. 79. Academic Press, London.

Attar, A. and Dupuis, F., 1979, The rate and fundamental mechanism of the reaction of hydrogen sulphide with the basic minerals in coal. Ind. Engng Chem. Process Des. Dev. $18,607-618$. 
Barin, I., 1989, Thermochemical Data of Pure Substances. VCH Verlagsgesellschaft mbH, Weinheim, Germany.

Borgwardt, R. H. and Roache, N. F., 1984, Reaction of $\mathrm{H}_{2} \mathrm{~S}$ and sulphur with limestone particles. Ind. Engng Chem. Process Des. Dev. 23, 742-748

Borgwardt, R. H., Roache, N. F. and Bruce, R. B., 1984, Surface area of calcium oxide and kinetics of calcium sulphide formation. Environ. Progr. 3, 129-135.

Clift, R. and Seville, J. P. K. (Eds), 1993, Gas Cleaning at High Temperatures. Blackie Academic \& Professional, London.

Duo, W., Seville, J. P. K., Kirkby, N. F. and Clift, R., 1994, Formation of product layer in solid-gas reactions for removal of acid gases, Paper Presented at the $13^{\text {th }}$ International Symposium on Chem. Reac. Engng, September 25-28, Baltimore, MD.

Ham van der, A. G. J., Heesink, A. B. M., Prins, W. and van Swaaij, W. P. M., 1995, Regenerative high-temperature coal gas clean-up with calcined limestone: some scouting experiments (in preparation).

Heesink, A. B. M., Prins, W. and van Swaaij, W. P. M., 1993 A grain size distribution model for non-catalytic gas-solid reaction. Chem. Engng J. 53, 25-37.

Heesink, A. B. M. and van Swaaij, W. P. M., 1995, The adsorption of $\mathrm{H}_{2} \mathrm{~S}$ on sulphided limestone. Chem. Engng $S c i$. (in press).

Illerup, J. B., Dam-Johansen, K. and Johnsson, J. E., 1993, Hydrogen sulphide retention on limestone at high temperature and high pressure. In Gas Cleaning at High Temperatures (Edited by R. Clift, and J. P. K. Seville), pp. 492-509. Blackie Academic \& Professional, London.

Kamath, V. S. and Petrie, T. W., 1981, Rate of reaction of hydrogen sulphide-carbonyl sulphide mixture with fully calcined dolomite. Eniviron. Sci. Technol. 15, 966-968.

Nguyen, Q. T. and Watkinson, A. P., 1993, Sulphur capture during gasificaion of oil sand cokes, Can. J. Chem. Engng 71, 401-410.

Pell, M., 1971, Reaction of hydrogen sulphide with fully calcined dolomite, Ph.D. thesis, The City University of New York, U.S.A.

Proy, G., 1982, Entschwefelung heisser reduzierender Gase mit Metalloxiden. Glükauf-Forshungshefte 43 (H.3), 105-114.

Sotirchos, S. V., 1991, Comparative study of the reactions of metal oxides with $\mathrm{SO}_{2}$ and $\mathrm{H}_{2} \mathrm{~S}$. In Proceedings of the 11 th Annual Gasification and Gas Stream Cleanup Systems Contractors Review Meeting (Edited by V. K. Venkataraman, L. K. Rath, J. W. Martin, R. C. Bedick), DOE/METC91/6123.

Squires, A. M., Graff, R. A. and Pell, M., 1969, Desulphurization of fuels with calcined dolomite, I. Introduction and first kinetic results. Chem. Engng Progr. Symp. Ser. 67, 23-34.

Szekely, J. and Evans, J. W., 1970, A structural model for gas-solid reactions with a moving boundary. Chem. Engng Sci. 25, 1091-1107.

Venkataraman, V. K., Rath, L. K., Martin, J. W., Bedick, R. C. (Eds), 1991, Proceedings of the 11th Annual Gasification and Gas stream Cleanup Systems Contractors Review Metting, DOE/METC-91/6123.

Westmoreland, P. R. and Harrison, D. P., 1976, Evaluation of candidate solids for high-temperature desulphurization of low-BTU gases. Environ. Sci. Technol. 10, 659-661.

Westmoreland, P. R. Gibson, J. B. and Harrison, D. P., 1977, Comparative kinetics of high-temperature reaction between $\mathrm{H}_{2} \mathrm{~S}$ and selected metal oxides. Environ. Sci. Tech nol. 11, 488-491.

Wigmans, T., Elfring, M. and Moulijn, J. A., 1983, Mass transfer phenomena during potassium carbonate catalysed carbon steam gasification reactions in a microbalance setup. Carbon 21, 23-31.

Yagi, S. and Kunii, D., 1955, Proceedings of the 5th Symposium (International) on Combustion, Reinhold, New York, p. 231.

Yang, R. T. and Chen, J. M., 1979, Kinetics of desulphurization of hot fuel gas with calcium oxide. Reaction between carbonyl sulphide and calcium oxide. Environ. Sci. Technol. 13, 549-553.

Yumura, M. and Furimsky, E., 1985, Comparison of $\mathrm{CaO}$, $\mathrm{ZnO}$ and $\mathrm{Fe}_{2} \mathrm{O}_{3}$ as $\mathrm{H}_{2} \mathrm{~S}$ adsorbents at high temperatures. Ind. Engng Chem. Process Des. Dev. 24, 1165-1168. 